\title{
Liselerde Disiplin Uygulamalarına Yönelik Öğretmen ve Öğrenci Görüssleri
}

\author{
DOI: $10.26466 /$ opus.868503
}

\author{
* \\ Fatma Sadık ${ }^{*}$ Onur Yalçın** \\ *Doç.Dr., Çukurova Üniversitesi Eğitim Fakültesi Eğitim Bilimleri Bölümü, Adana/Türkiye \\ E-Posta: fatmasdk@gmail.com \\ ORCID: $\underline{0000-0002-6565-5679}$ \\ E-Posta: o.yalcin81@gmail.com \\ ${ }^{* *}$ Dr., Milli Eğitim Bakanlığı, Adana/Türkiye \\ ORCID: $\underline{0000-0002-4219-9295}$
}

\section{Öz}

$B u$ araştırma, liselerdeki disiplin uygulamalarına yönelik öğretmen ve öğrenci görüşlerini derinlemesine inceleyen bir olgu bilim araştırmasıdır. Araştırma Adana il merkezindeki bir meslek lisesindeki 18 öğretmen ve 16 öğrenciyle gerçekleştirilmiştir. Veriler, araştırmacılar tarafindan geliştirilen yarı yapılandırılmış görüşme formu ile toplanmış, içerik analizi yöntemiyle çözümlenmiştir. Araştırma sonucunda disiplin sorunları karşısında katılımcıların çoğunluğunun ceza verme, dolaylı olarak uyarma, öğrenci ile iletişim kurma ve öğrencide farkındalık oluşturma yöntemlerinin uygulandı̆̆ı konusunda hem fikir olduklar görülmüş̧ür. Disiplini sağlamada en sık kullanılan yöntemler ise cezalandırma, öğrenci ile iletişim kurma olmuş; öğrenci ile iletişime geçme, empatik dinleme ve ders dışında öğrenciyle zaman geçirme ise daha etkili yöntemler olarak algilanmıştır. Elde edilen sonuçlar öğretmenlerin kabalık, derse karşı ilgisizlik, ders akışını engelleme ve sorumlulukların yerine getirmemeyle ilgili disiplin sorunların yönetmede daha yeterli algılandıkların göstermiştir. Öğrencilerin kendilerinin, velilerin de çocuklarının hataların kabul etmemesi, öğretmenlerin öğrencilerle iletişim kuramamaları, davranışın sını geneline yayılması ve sınıfta hâkimiyetin kaybolması disiplin sürecinde yaşanan sorunlar olarak saptanmıştır. Katılımcıların tamamı etkili disiplin için öğretmenlerin gelişimi üzerinde durmuş, öğretmenler paydaşlarla işbirliği yapma gerekliliğini, öğrenciler ise öğretmenlerin öğrenci farkındalığını arttırma becerilerini vurgulamışlardır. Öğretmen ve öğrenci görüşlerine göre okul ortamında öğrenci ihtiyaçlarına yönelik düzenlemeler, eğitimle ilgili yasa ve yönetmeliklerde işlevsel yenilikler, öğrenci ve velilerin gelişimi desteklemek disiplinde etkililiği arttırmanin diğer yollarıdır.

Anahtar Kelimeler: Disiplin, Disiplin problemleri, Lise, Öğrenci, Öğretmen. 


\title{
The Views of Teachers and Students on Disciplinary Practices in High Schools
}

\begin{abstract}
This research is a phenomenological study examining the views of teachers and studentson disciplinary practices in high schools in depth. The study was conducted with 18 teachers and 16 students in a vocational high school in the city center of Adana. The data were collected using a semi-structured interview form, which was developed by the researchers, and analyzed by the content analysis method. As a result of the study, it was observed that the majority of the participants agreed that the methods of punishment, indirect warning, communication with the student, and raising awareness in the student were applied for disciplinary problems. While the most common methods used in achieving discipline were punishment and communication with the student, empathic listening, communication with the student and spending time with the student outside the course were perceived as more effective methods. The results indicated that teachers were perceived more adequately in managing disciplinary problems related to rudeness, indifference to the course, disrupting the course flow, and failure to fulfill responsibilities. Students' refusal to accept their own mistakes, parents' refusal to accept their children's mistakes, teachers' inability to communicate with students, the spread of behavior across the classroom, and the loss of classroom dominance were determined as the problems experienced in the disciplinary process. All of the participants emphasized the change and development of teachers for effective discipline, and teachers emphasized the need to collaborate with stakeholders. However, students emphasized teachers' professional development and student awareness-raising skills. According to the views of teachers and students, arrangements for students' needs in the school environment, functional innovations in the laws and regulations related to education are other ways to increase the effectiveness in the discipline.
\end{abstract}

Keywords: Discipline, Disciplinary Problems, High School, Student, Teacher. 


\section{Giriş}

Öğrencilerin çok yönlü gelişimini sağlamak, onlara toplu yaşam bilinci kazandırarak sağlıklı bir şekilde yetişkin yaşamına hazırlamak eğitimin temel amaçlarındandır. Eğitimin bilgi, beceri ve duygu boyutlarında tanımlanmış amaçlarına ulaşmasında sınıfta yapılan öğretim etkinliklerinin uygunluğu ve niteliği kadar sınıfın sosyal yapısı da büyük öneme sahiptir (Aydın, 2006). Çünkü sınıf farklı özelliklere sahip (bilgilere, becerilere, sosyo-kültürel özelliklere, tutumlara, algglara vb.) öğrencilerin öğrenmek için bir araya geldikleri ve günün büyük bir bölümünü birlikte geçirdikleri bir yaşam alanıdır (Gökyer ve Doğan, 2016). Etkili öğrenme için düzenli, güvenli bir ortam ve sağlıklı iletişim gereklidir. Bu da disiplinle sağlanır. Bu açıdan bakıldığında disiplin toplumsal alan içindeki tüm bireylerin "ortak" iyiliği için, eşit mesafede, açıkça belirlenmiş akılcı kuralları ve bunlara uyulması için alınması gereken tüm önlemleri ifade eder (Kök, 2007). Bu amaca yönelik olarak çocuklara okulda ve sınıf ortamında ihtiyaç duydukları sınırlar konularak, sağlıkla gelişebilecekleri güvenli ortam sağlanmaya çalışılır. Bunlar sessiz olma, düzenli olma, öğrenmenin gereklerini yerine getirme gibi öğretmen ediminin göstergelerinin yanı sıra, okul güvenliği, zamanlama, sürecin planlar çerçevesinde işleyişi gibi okul yönetimini ilgilendiren boyutlara da sahiptir (Raby, 2012). Bu kural ve uygulamalar ile çocuklara toplum kuralları, toplumun uygun bulduğu davranışlar ve etkili birer birey olabilmeleri için gerekli olan özellikler kazandırılmak amaçlanır.

Öğretmenlerde öğrencilerden genellikle farklılıklara saygı duymalarını, öğretmenleri ve diğer öğrencilerle sağlıklı iletişim kurmalarını, akademik ve sosyal sorumlulukların yerine getirmelerini beklerler (Evertson ve Emmer, 2012). Öğrenciler farklı nedenlerle bu beklentilerin dışında davranışlar sergilediklerinde ise sınıf içinde öğrenme-öğretme çabalarını aksatan, ilişkileri ve duyguları olumsuz etkileyen durumlar ortaya çıkar. Disiplin sorunu olarak tanımlanan bu davranışlar bir bakıma öğretmenlerin beklentileri/kurallar ile öğrencilerin davranışları arasındaki farktır (Infantino ve Little, 2005). Toplumsal düzen davranışlara müdahale edilmesini gerektirdiğinden, bu noktada öğretmenlerin sorun davranışları nasıl ele aldıkları/yönettikleri çok büyük önem kazanmaktadır. Çünkü disiplinin amacı, çocukların doğru ile yanlışı, iyi ile kötü arasındaki farkları ayırmaları ve kendilerini kontrol etme/öz denetim becerilerini kazanmalarıdır (Yavuzer, 2013). Bu açıdan 
bakıldığında disiplin çok boyutlu bir kavram olup, ceza sadece bir boyutunu oluşturmaktadır. Disiplin, çocuğun benlik değerinin temelini oluşturma, başkalarını anlama ve onların kişiliklerine saygı gösterme, yardımsever olma gibi temel duyguları güçlendirmedir (Ada ve Ölçüm Çetin, 2006; Humphresy, 1998; Yavuzer, 2013). Karşlıklı sevgiye ve güvene dayalı bir iletişim disipline eşlik ettiğinde çocuklara davranışlarının ve kişiliklerinin doğru yönde şekillenmesi için en ideal sınıf ortamı sağlanmış olur. Bunun için öğretmenlerin öğrencilerini yakından tanımaları, onların ilgi ve ihtiyaçlarını gözeterek, yerinde ve zamanında doğru yönlendirmelerle onları hayata hazırlamaları gerekmektedir (Yılmaz ve Babaoğlan, 2013). Öğretmenlerin sorun davranışları sosyal, hukuki ve pedagojik açıdan uygun şekilde ele almaları, sadece tekrarlanmasını önleme değil, öğrencilere doğru şekilde nasıl davranılacağını öğretme açısından çok önemli bir etkiye sahiptir (Wehby, Tally ve Falk, 2004). Çünkü bireyler özellikle çocuklar ve gençler çevrelerinden, medyadan ve çeşitli yollardan gördüklerini model olarak aldıklarından, öğretmenler öğrencilerin model alabilecekleri biçimde davranmalı, öğrencilerin kendilerinin ve başkalarının duygularını anlamalarına, kendi arzularını kontrol etmelerine yardımcı olmalıdır (Yavuzer, 2013).

Ancak davranışla ilgili algılar; kişisel yargılar, değerler, inançlar, ihtiyaçlar, yaşam şekli, davranışı yapan kişinin yaşı, davranışın gerçekleştiği ortam, davranışın sürekliliği, davranışın ortama, çevreye ve kişilere verdiği zarar vb. birçok değişkene göre farklılaşabilmektedir. Bu nedenle hangi davranışların disiplin sorunu olduğu sadece öğretmenlerin değil öğrencilerin de davranışı ve sonuçlarını nasıl algıladığına bağlıdır. Ayrıca yaşam şartları, eğitim politikaları, okul programları ve öğretmen-öğrenci rolleriyle ilgili eğitim anlayışlarının da zamanla değiştiği göz önünde bulundurmalıdır. Çünkü bunlara bağlı olarak öğretmen ve öğrencilerin birbirlerini ve davranış biçimlerini algılama ve değerlendirme ölçütleri değişmektedir. Dolayısıyla eğitim ortamlarında disiplin sorunu olan davranışlar ve disiplini sağlamada nasıl bir yol izleneceği, en etkili yaklaşım, yöntem ya da stratejilerin hangisi/hangileri olduğu sorularının tek bir cevabı yoktur (Charles, 2005). Bununla birlikte ilgili literatürde disiplinin nasıl sağlanacağı sorusuna cevap arayan çeşitli disiplin modellerine rastlanmaktadır.

Örneğin Skinner'in Davranış Değiştirme Modeli, yüksek öğretmen kontrolüne dayalı bir modeldir. Çevresel uyaranlar doğru sunulduğunda davranışın olumlu yönde şekillendirilebileceğini savunan modelin temelini 
edimsel koşullama oluşturmaktadır. Pekiştireçler; yeni bir davranış oluşturma, var olan davranışı güçlendirme, oturmuş bir davranışı sürdürme, uygun olmayan davranışı durdurma ve duygusal davranışı değiştirme amaçlı kullanılır. Yaklaşıma göre sorun davranışı düzeltmek için planlı hareket edilmeli, öncelikle davranış ve çevre ilişkileri iyi açılanmalıdır. Etkili davranış yönetimi öğrencinin davranışını, olası nedenlerini, davranışın meydana gelme sıklığını gözlemeyi, davranışın sınıf ortamındaki belirleyicileri (öncül) ve sonuçlarını (artçl) analiz ederek plan yapmayı gerektirmektedir (Charles, 2005; Tekin İftar, 2014).

Atılgan Disiplin Modeli'nin odağı, öğretmen ve öğrenci ihtiyaçlarının karşılandığı, davranışların insanca yönetildiği ve öğrenme odaklı bir sınıf ortamı oluşturmaktır. Bu amaç, öğrencilerin ihtiyaçlarıyla dikkatli bir şekilde ilgilenerek, davranış kurallarını oluşturarak, öğrencilere düzenli olarak uygun şekilde nasıl davranacaklarını öğreterek, yanlış davranış sergileyen öğrencilerle karşılıklı güven ve saygı ortamında yönlendirici konuşmalar yapılarak başarılır. Bu açıdan yüksek öğretmen kontrolüne dayanan bu model, sözlü atılgan eğitim ile ödül ve cezaları kullanan öğretmenlerin sistematik bir kombinasyonu olarak nitelenir. Etkili disiplin için bir disiplin planı hazırlanmalı, öğrencilere öğretilmeli ve sonra uygulamaya konulmalıdır. Hazırlanan disiplin planı; sınıf kurallarını, kurallara uyan öğrencilere yönelik olumlu kabul eylemlerini, kuralların çiğnenmesinin yaratacağı sonuçları (mantıksal yaptırımlar) içermelidir (Canter ve Canter, 2013; Charles, 2005; Edwards, 2004).

Kounin'nin Öğretimsel Disiplin Modeli, uygun olmayan davranısların yönetiminden ziyade disiplin sorunlarını önlemede öğretim aktivitelerinin ivmesi ve akıcılığı üzerinde durmaktadır. İvme; ders içerisinde bir aktiviteden diğerine geçerken bütün öğrencilerin buna hazır olmasını sağlamadır. Akıcılık ise; öğretmenin konuya, sınıf düzeyine ve öğrencilerin öğrenme hızına uygun seviyeyi bulma ve uygulama becerisi olarak tanımlanır. Eğer öğretmenler sınıf içerisinde bu noktalara dikkat etmezlerse öğretimde düzensizlik veya gecikme meydana gelir. Öğretmenlerin öğrenci davranışlarına müdahalesi ve uyarıları artar. Uyarma bağımlılığı artıkça ders etkinlikleri arasında geçişlerin uyumu bozulur (Arak ve Aslan, 2008; Edwards, 2012; Hönicke, 2003; Pala, 2010). 
Glasser'in Geliştirdiği Gerçeklik Terapisi Modeli öğrencilerin sorun davranışlarının nedenini karşılanamayan ihtiyaçlarla açıklar. Okul ortamlarındaki geleneksel yapının öğrencilerin temel ihtiyaçlarını (ait olma, güç, eğlence ve özgürlük ihtiyacı) karşılamadığı ve öğrencileri okuldan uzaklaştırdığı belirtilir. Disiplinin amacı öğrencilere temel ihtiyaçlarını nasıl karşılayacaklarını öğreterek, olumsuz davranış ve eylemlerden uzaklaşmalarını ve başarılı kimlik geliştirmelerini sağlamaktır. Bunun için öğrencilerin gösterdikleri davranışların bütün sonuçlarını inceleyerek, davranışlarını yönetmeyi öğrenmeleri gerekmektedir (oto kontrol). Uygulamada öğretmen ve yöneticiler daha az otoriter, öğrenciler ise daha fazla sorumluluk sahibidir. Öğrencilerle birlikte sınıf kuralların belirleme, sorun davranışlanı birlikte inceleyerek farkındalık oluşturma, sorumlu davranış biçiminin ne olduğuna karar verme, davranış plan yapma ve uygulamaya koyma modelin uygulanmasında izlenen adımlardır (Burden, 1995; Tauber, 2007; Tertemiz, 2012).

Karşılanamayan ihtiyaçlar üzerinde duran bir diğer bilim insanı Dreikurs'a göre ise insanlar doğuştan sosyal gruplara ait olma ihtiyacı duyan sosyal varlıklardır. Ancak bazı öğrencilerde aidiyet duygusu daha zor gelişmekte, bu duyguyu yaşayamayan öğrenciler yanlış hedeflere (dikkat çekme, güç kazanma, intikam alma, yetersizlik) yönelebilmektedir. Bu nedenle Sosyal Disiplin/Mantıksal Sonuçlar Modeli'ne göre disiplinin anahtarı, öğrencinin davranışını yönlendiren yanlış hedefleri keşfetmesini ve doğru amaçlara yönelmesini sağlamaktır. Bir bakıma okullar çocukların ideallerinin ve demokratik davranış kapasitelerinin geliştirildiği yerler olmalıdır (Tümkaya, 2005). Öğretmenler çocuklara kendi seçimlerini yapma şansı vermeli ve yaptıkların seçimlerin doğal ve mantıksal sonuçlarını kabul etmelerini sağlamalıdır. Disiplin en iyi şekilde, öğrenciler ve öğretmenlerin birlikte karar aldıklarında sağlanır. Bu süreç onların kuralların ve sonuçların arkasındaki nedenleri anlamalarını sağlar ve davranışların istenen veya istenmeyen sonuçları ürettiğini görmelerine yardımcı olur (Tauber, 2007; Wolfgang, 2008).

Öğretmen Etkililiği Eğitimi Modeli'nde öğretmen ve öğrenci arasındaki ilişkinin kalitesi ön plandadır. Düşük düzeyde öğretmen kontrolü içeren model, iletişim becerilerinin nasıl geliştirilebileceği ve etkili bir iletişimin nasıl olması gerektiği üzerinde durmaktadır. Öğrencilerin sorun çözme ve karar verme becerilerini geliştirebilmek için öğrencilerin ihtiyaçlarına sayg1 duyma, öğrenmede özgürlük sağlama, sınıf içinde demokrasi ortamını 
oluşturma öne çkan uygulamalardır. Öğrencilerin sorun davranışlarıyla yüzleşebilmeleri ve çözme sürecinin verimli olması için; sorunu tanımlama, olası çözümler üretme, çözümleri değerlendirme, karar verme, kararın nasıl uygulanacağını belirleme ve çözümün başarısını değerlendirme aşamalarının izlenmesi önerilir. Sevgi, saygı, güven ve açk iletişim sayesinde her durum yeniden yapılandırılabilir. Böylece kimse kaybetmez, kırgınlıklar olmaz, öğrencilerin problem çözme becerileri gelişir, öğretmen ve öğrenci birlikte sonuç üretirler (Ağrın, 2019; Gordon, 2019; Öz, 2012).

Görüldügü gibi her bir disiplin modelin davranışa bakış açısı ve davranış yönetiminde öğretmene ve öğrenciye yüklediği sorumluluklar farklıdır. Bununla birlikte genel olarak önleyici ve etkileşimci yaklaşımlar benimsedikleri söylenebilir. Önleyici yaklaşımlar daha geleneksel olup, öğretmen müdahalesine dayanmaktadır. Ödül ve cezalar öğretmen tarafından açıç̧a tanımlanmakta, öğrenciler yaptıkları şeylerin karşlığını görecekleri konusunda bilinçlendirilmektedir. Etkileşimci yaklaşımlar ise daha humanist /insancıl olup, disiplini içsel kontrolü sağlamaya yarayan katılıma bir süreç olarak tanımlamaktadırlar. Öğrenci ihtiyaçlarına önem veren bu yaklaşımlarda içsel kontrolü sağlama konusunda öğrenciyle işbirliği yapılmakta, duruma göre davranış kontrolü öğrenciyle paylaşılmakta veya kontrol tamamen öğrenciye bırakılmaktadır. Disiplin çaba ve beceri gerektiren bir öğrenme süreci olarak görülmektedir. Hangi disiplin yaklaşımından söz edilirse edilsin, her yaklaşımın dayandığı bir felsefi arka plan ve bu arka plandan kaynaklı model ve stratejilerle somutlaşan bir eylem boyutu söz konusudur. Öğretmenler de düşünsel arka planlarından hareketle stratejilerini belirlemektedirler (Tunç, Yıldız ve Doğan, 2015).

Sonuç olarak her öğretmenin sınıfında disiplin problemleri az-çok yaşanır. Önemli olan sınıf ortamının doğal bir parçası olan disiplin sorunlarını etkili yönetebilmektir. Etkili davranış yönetimi için her durumun kendi koşullarında ele alınması, o duruma uygun stratejilerin işe koşularak, işlevselliğinin değerlendirilmesi gerekmektedir (Weber, 2003). Aynı davranış farklı öğrencilerde gözlenebilir, ancak öğrencileri bu şekilde davranmaya iten nedenler farklılık gösterebilir veya öğrenciler aynı neden/nedenlerle farklı davranışlar sergileyebilirler. Bu nedenle her disiplin sorununa uygun evrensel bir modelden bahsetmek, disiplin problemleri karşısında tek bir modele ve stratejilerine bağlı kalmak mümkün değildir (Tauber, 2007). Aksi takdirde sorun davranışlar daha da güçlenebilmekte, sınıf geneline yayılabilmekte 
veya yeni sorunlar ortaya çıkabilmektedir (Sarıtaş, 2006). Yapılan araştırmalara göre disiplin sorunlarındaki süreklilik öğretmenlerin motivasyonlarını ve eğitimin kalitesini düşürmekte (Çerçi, 2009; Livumbaze, 2017; Martin ve Pear, 2007; Masekoameng, 2010; Ombira ve Aluko, 2011-2012; Salifu ve Agbenyega, 2012) sınıf ortamını bozarak öğrencilerinde öğrenme çabasından uzaklaşmasına neden olmaktadır (Arens, Morin ve Watermann, 2015; Hanhan, 2012; PISA, 2011; Sürücü ve Ünal, 2018). Dolayısıyla etkili okullar ve sağlıklı bir toplum için disiplinle ilgili çalışmaların gerekliliği ve önemi giderek artmaktadir.

İlgili literatür incelendiğinde konuyla ilgili araştırmaların daha çok okulöncesi ve ilkokul öğretmenleriyle yapıldığı görülmektedir (Aküzüm ve Nazlı, 2017; Çankaya ve Çanakçı, 2011; Çelikkaleli, 2010; Çetin, 2013; Erzurum ve Kır, 2011; Güder, Alabay ve Güner, 2018; Gündüz ve Konuk, 2016; Konti, 2011; Ocak Karabay ve Şahïn As1, 2019; Öngören Özdemir ve Tepeli, 2016; Öztürk ve Gangal, 2016; Temiz, 2020; Uysal, Altun ve Akgün, 2010). Disiplinin çocuk eğitiminin ayrılmaz bir parçası olması, çocuğun psikolojisinde ve gelişiminde önemli rol oynaması nedeniyle bu son derece doğaldır. Çünkü hiçbir çocuk sınırları bilerek doğmaz. Bu açıdan anne-baba ve öğretmenler birincil öneme sahip yetişkinlerdir. Evde ebeveynlerin, okullarda öğretmenlerin görevi çocuklara bu sinırları öğreterek, zamanla özdisiplinlerini edinmelerine yardımcı olmaktır. Bu açıdan okulöncesi ve ilkokul temel eğitim basamaklarıdır. Bununla birlikte disiplin bir öğrenme sürecidir. Bu nedenle, her eğitim sisteminde ve eğitim kademesinde disiplin vardır. Ortaokul kademesinde nispeten daha az çalışma olmakla birlikte öğretmenlerin yanı sıra öğrenci görüşlerine de başvurulan araştırmalara rastlanmaktadır (Andegiorgis, 2020; Demir, 2013; Gökçen, 2018; İnce, 2011; Kyriacou ve Martín, 2010; Koutroba, 2011; Öz, 2012, Öztürk, 2016; Pehlivan, 2017; Temitayo, Nayaya ve Lukman, 2013; Yahaya, Ramli, Hashim, Ibrahim, Rahman ve Yahaya, 2009; Yıldırım, 2010). Bu araştırmalardan elde edilen ortak sonuçlar sınıfta disiplinin çoğunlukla sorun davranışı durdurmaya yönelik girişimlerle; öğrenciye doğru yürüme, göz teması kurma, derse ara verme, ceza verme, pekiştireç, sorumluluk verme, uyarma yöntemleriyle sağlanmaya çalışıldığını göstermektedir. Bu doğrultuda eğitim kademeleri farklı olmakla birlikte öğretmenlerin disiplini sağlamak için öğretmen müdahalesine dayanan stratejilere öncelik verdikleri söylenebilir. 
Oysa etkili disiplin için öğretmenlerin öğrencinin yaşına ve gelişim özelliklerine de dikkat etmeleri, zamanla öğrencilere kendi davranışlarının sorumluğunu ve kontrolünü vermeleri gerekmektedir. Bu durum özellikle liselerde çok daha büyük önem taşımaktadır. Çünkü ergenlik dönemi soyut düşünmeye paralel olarak ahlaki olgunluğa yönelmenin gerçekleştiği dönemdir. Bu yaş dönemindeki çocuklar (15-18 yaş) fiziksel ve duygusal açıdan hızlı değişimler yaşamakta, çevreleriyle ve kendileriyle tutarsız davranışlar sergileyebilmektedir. Bu nedenle ergenlik dönemi gerek değerlerin kazandırılmasında gerekse ergenlerin değişen topluma ayak uydurmaları açısından da en kritik dönemdir. Çocuğun çevresindeki yetişkinlerin; özellikle günün büyük bölümünü birlikte geçirdikleri öğretmenlerin ergenden doğru olan üzerinde düşünmesini, doğruyu bulmasını istemesi öz denetim becerilerinin yanı sıra değer ve vicdan gelişimini hızlandırmak açısından da gereklidir (Koç, 2004).

$\mathrm{Bu}$ doğrultuda lise düzeyinde disiplinin nasıl sağlandığına yönelik araştırmalar incelenmiş, ancak ulaşılabilen araştırmaların okul genelinde işlenen ergen suçlarına, disiplin suçlarının nedenlerine, verilen disiplin cezalarına, yönetsel düzenlemelere ve akran zorbalığına odaklandığı görülmüştür (Akar, 2006; Akpınar ve Özdaş, 2013; Bilir, Kuru ve Tezcan, 2007; Duran, 2011; Güçlü Yılmaz, 2015; Gümüş, 2013; Hanhan, 2012; Kahveci, 2012; Pehlivan ve Demirtaş, 2019; Toytok ve Yıldırım, 2018; Yücesoy, 2017). Disiplin algısı ve disiplinin nasıl sağlandığıyla ilgili çalısmaların ise diğer eğitim kademelerine göre sınırlı sayıda olduğu saptanmıştır (Aktaş, 2019; Gökyer ve Doğan, 2016; Kaçar, 2018; Samue, Owusu, Prince ve Gyamera, 2015; Siyez, 2009; Sueb, 2013; Tunç, Yıldız ve Doğan 2015; Zachos, Delaveridou ve Gkontzou, 2016). Bu gerekçelerden hareketle liselerde disiplin uygulamalarını öğretmen ve öğrencilerin bakış açısından inceleyen bir araştırma yapmaya gereksinim duyulmuştur. Araştırmadan elde edilen sonuçlar aynı sınıf ortamını paylaşan kişilerin sınıf içi yaşantıları nasıl değerlendirdiğini göstermesi ve disiplini sağlamaya yönelik izlenen süreçlerin pedagojik açıdan uygunluğunu tartışma açısından önemlidir. Araştırmada aşağıdaki sorulara yanit aranmıştır:

1. Sınıfta disiplin sorunları karşısında nasıl bir yol izlenmektedir?

2. Disiplini sağlamada en sık kullanılan ve en etkili olan yöntemler hakkında görüşler nasıldır? 
3. Öğretmenlerin disiplin sorunlarını ele alma/yönetme yeterlilikleri hakkında görüşler nasıldır?

4. Sınıfta disiplini sağlama sürecinde ne tür sorunlar yaşanmaktadır?

5. Disiplin sorunlarını önlemek ve kalıcı çözümler üretmek için nasıl bir yol izlenmelidir?

\section{Yöntem}

\section{Araştırmanın Modeli}

Liselerdeki disiplin uygulamaları hakkında öğretmen ve öğrenci görüşlerini derinlemesine incelemeye yönelik bu araştırma nitel desende gerçekleştirilmiştir. Nitel çalışmaların amacı kavramları, olguları, ilişkileri gözlem, görüşme ve doküman incelemesi gibi veri toplama yöntemleriyle açıklamaya ve anlamaya çalışmaktır (Merriam, 2013). Bu araştırma nitel araştırma desenlerinden olgu bilim araştırmasıdır. Olgu bilim araştırmaları bir olguyu daha iyi anlamamıza yardımcı olacak sonuçları sağlayacak örnekler, açıklamalar ve yaşantılar ortaya koymayı amaçlayan araştırmalardır (Cropley, 2002). Veri kaynakları araştırmanın odaklandığı olguyu yaşayan ve bu olguyu yansitabilecek birey/ gruplardır. Bu araştırmada odaklanılan olgu disiplin, görüşlerine başvurulan kişiler ise öğretmen ve öğrencilerdir.

\section{Katılımcilar}

Araştırma Adana merkezindeki bir meslek lisesindeki öğretmen ve öğrencilerle gerçekleştirilmiştir. Okulun belirlenmesinde tipik durum örneklemesi yapılmıştır. Bu yöntemde araştırmaya konu olan durumu en genişs şekliyle tasvir eden örneklemi bulmak, böylece normal yada siradan durumları belirlemek amaçlanır (Creswell, 2012). Belirlenen okul il merkezinde, öğretmen ve öğrenciler için ulaşımı kolay, öğrenci sayısı fazla olan büyük meslek liselerinden biridir. Öğretmenlerin belirlenmesinde maksimumum çeşitlilik sağlanmaya çalışılmış, çeşitlilik gösteren durumlar arasında herhangi bir ortak ya da paylaşılan olguların olup olmadığını bularak, problemin farklı boyutlarını ortaya koymak amaçlanmıştır. Bu doğrultuda öğretmenlerin farklı branşlarda, farklı sınıf düzeylerinde derse giren ve hizmet süreleri 
farklı öğretmenler olmasına dikkat edilmiştir (Glesne, 2013). Öğrencilerin belirlenmesinde ise ölçüt örnekleme yapılmış, belirlenen öğretmenlerin dersine girdikleri sınıf düzeylerinin (9-12.sınıf) her birinden iki kız ve iki erkek olmak üzere toplam 16 öğrenci araştırmaya katılmıştır. Her iki grupta da katılımcılar gönüllü olan öğretmen ve öğrenciler arasından seçilmiştir. Tablo 1 'de araştırmaya katılan 18 öğretmenin demografik bilgileri yer almaktadır.

Tablo 1. Öğretmenlerin Demografik Bilgileri

\begin{tabular}{llll}
\hline Cinsiyet & f & Branş & f \\
\hline Kadın & 10 & Türk Dili ve Edebiyat & 4 \\
Erkek & 8 & Matematik & 3 \\
Hizmet Yılı & & İngilizce & 3 \\
$1-5$ yll & 5 & Coğrafya & 2 \\
$5-10$ Yll & 3 & Kimya & 2 \\
$10-15$ Yıl & 7 & Fizik & 2 \\
$15-20$ yıl & 3 & Biyoloji & 1 \\
Eğitim durumu & & Tarih & 1 \\
Lisans & 14 & Daha Çok Girilen Sınıf & \\
Lisansüstü & 4 & 9 & 6 \\
Mezun Olunan Fakülte & & 10 & 5 \\
Eğitim Fakültesi & 12 & 11 & 4 \\
Fen Edebiyat Fakültesi & 6 & 12 & 3 \\
Formasyon Dersleri & & Öğrenci Sayısı & \\
Lisans eğitimi sirasinda & 14 & $21-30$ arası & 15 \\
Lisans Eğitimi Sonrası Formasyon & 4 & $31-40$ arası & 3 \\
\hline
\end{tabular}

Tablo 1'de görüldüğü gibi öğretmenlerin sekizi erkek, 10' u kadındır. Çoğunluğu 10-15 yıllık hizmet süresine sahip (f:7), eğitim fakültesi mezunu öğretmenlerdir (f:12). Öğretmenler formasyon derslerini (f:14) lisans eğitimi sırasında almışlardır. Öğretmenlerin branşları farklı olup, (Türk dili ve edebiyatı, Matematik, İngilizce, Coğrafya, Kimya, Fizik, Biyoloji ve Tarih) tüm sınıf düzeylerinde derslere girmektedirler. Öğretmenlerin sınıflarındaki öğrenci sayısı çoğunlukla 21-30 arasındadır. Öğrencilerin özelliklerine ait bilgiler Tablo 2' de yer almaktadır.

Tablo 2 incelendiğinde öğrencilerin sekizinin kadın, sekizinin erkek olduğu görülmektedir. Öğrencilerin anne ve babaları çoğunlukla ilkokul mezunudur. Anneler evhanımı (f:15) babaları ise serbest meslek (f:5), işçi (f:3), işsiz (f:3), şoför (f:2) ve emekli (f:1) gibi farklı işlerde çalışmaktadır. Öğrencilerin ailelerinin aylık geliri genellikle 1000-1500 TL arasında değişmekte olup, kirada oturdukları görülmektedir (f:10). 
Tablo 2. Öğrencilerin Demografik Bilgileri

\begin{tabular}{|c|c|c|c|}
\hline Cinsiyet & $\mathbf{f}$ & Anne Meslek & $f$ \\
\hline Kadın & 8 & Ev hanımı & 15 \\
\hline Erkek & 8 & Temizlikçi & 1 \\
\hline Kardeş sayısı & & Baba Meslek & \\
\hline Bir kardeş & 3 & Serbest meslek & 7 \\
\hline İki kardeş & 3 & İşçi & 3 \\
\hline Üç kardeş & 4 & İşsiz & 3 \\
\hline Dört kardeş ve üzeri & 6 & Memur & 2 \\
\hline Anne Eğitim Durumu & & Emekli & 1 \\
\hline Okuma yazma bilmiyor & 3 & Ailenin Aylık Geliri & \\
\hline İlkokul & 9 & $500-1000$ & 5 \\
\hline Ortaokul & 1 & $1000-1500$ & 7 \\
\hline Lise & 3 & $1500-2000$ & 2 \\
\hline Baba Eğitim Durumu & & 2000 ve üzeri & 2 \\
\hline Okuma yazma bilmiyor & 2 & Evin Durumu & \\
\hline İlkokul & 8 & Kira & 10 \\
\hline Ortaokul & 2 & Kendilerine ait & 6 \\
\hline Lise & 4 & & \\
\hline
\end{tabular}

\section{Veri Toplama Araçları}

Araştırmada görüşme tekniği izlenmiş, verilerinin toplanmasında araştırmacılar tarafından ilgili literatür ve uzman görüşleri doğrultusunda geliştirilen görüşme formları kullanılmıştır. Görüşme tekniğinin kullanılma nedeni bireylerin araştırmaya konu olan olguyla ilgili iç dünyalarına girerek onların bilgi, tavır ve inançlarını anlamaktır. Görüşme soruları öğretmen ve öğrenciler için birbirine paralel hazırlanmış ve yarı yapılandırılmıştır. Soruların geçerlik çalışması için uzman görüşüne başvurulmuş, Ç.Ü Eğitim Fakültesi Eğitim Bilimleri Bölümünde görev yapan dört öğretim elemanının önerileri doğrultusunda sorular son şeklini almıştır. Uygulama öncesinde iki öğretmen ve iki öğrenciyle pilot çalışma yapılmış ve gelen dönütlerle sorular üzerinde gerekli düzeltmeler gerçekleştirilmiştir. Araştırma verileri 20142015 eğitim-öğretim yılı bahar döneminde toplanmış, yüz yüze gerçekleşen görüşmeler okulun gürültüden uzak ortamlarında (boş derslik ve rehberlik odası) katılımcıların izniyle ses kayıt cihazı kullanılarak yapılmıştır. Ortalama 20 dakika süren görüşmelerde herhangi bir sorun yaşanmamıştır. Öğretmen ve öğrencilere araştırmanın alt amaçlarına yönelik olarak altışar soru yöneltilmiştir. 


\section{Veri Analizi}

Çalışmada elde edilen veriler içerik analizi tekniğiyle analiz edilmiştir. İlk aşamada ses kayıtları Word ortamında yazıya dökülmüş, toplam 36 sayfa ham veri metni elde edilmiştir. İkinci aşamada ham veri metinleri araştırmacılar tarafından birbirinden bağımsız bir şekilde kodlanmış, Miles ve Huberman'ın (1994, s. 64) formülüyle her soru için ayrı ayrı hesaplanan kodlayıcı güvenirlikleri sınıfta disiplinin nasıl sağlandığı .84, disiplin sağlamada en sık kullanılan yöntemler .88 ve en etkili bulunan yöntemler .82 , disiplini sağlamada yaşanan sorunlar .81, öğretmenlerin disiplin sorunların çözme yeterlilikleri .89, disiplin sorunlarının çözümünde daha etkin kullanılabilecek yöntemler .90 olarak hesaplanmıştır. Görüş ayrılıklarının olduğu durumlarda araştırmacılar birlikte ortak karar almışlardır. Temaların oluşturulması sürecinde araştırmacılar birlikte çalışmış, karşılaştırma kolaylığ sağlaması açısından temalar ve altında yer alan kodlar tablolarla görselleştirilmiştir. Bulguların sunumunda öne çıkan tema ve kodlar açıklanmış, sık sık katılımcıların görüşlerinden alıntılara yer verilmiştir. Alıntılar sırasında öğretmen ve öğrenciyi tanımlamak için kodlar kullanılarak, katılımclar gizlenmiştir (Öğrt3K: görüşme yapılan üçüncü öğretmenin kadın, Öğr2E10: görüşme yapılan ikinci öğrencinin erkek ve 10.sınıf öğrencisi olduğunu göstermektedir).

\section{Bulgular}

Araştırma bulguları alt amaçlar doğrultusunda ve karşılaştırma kolaylı̆̆ı için öğretmen ve öğrenci görüşleri bir arada olacak şekilde sunulmuştur.

\section{Sınıfta Disiplin Sorunları Karşısında İzlenen Yöntemlerle İlgili Bulgular}

Katılımcılara ilk olarak sınıfta disiplin sorunları yaşandığında hangi yöntem ve tekniklerin kullanıldığı sorulmuş, verdikleri örnekler ve açıklamalarından elde edilen tema ve kodlar Tablo 3'te özetlenmiştir. Tablo 3'te görüldüğü gibi öğretmenlerin çoğu disiplin sorunları karşısında ceza verme (f:14), dolaylı uyarıda bulunma (f:12) ve öğrenci ile iletişime geçme (f:11) yöntemlerini kullandıklarını belirtmiştir. 
Tablo 3. Disiplin Sorunları Karşısında İzlenen Yöntemler

\begin{tabular}{|c|c|c|c|c|}
\hline Tema & Kod & Öğrt. & Öğr. & Top. \\
\hline & & $\mathrm{f}$ & $f$ & $\mathrm{f}$ \\
\hline \multirow[t]{9}{*}{ Ceza verme } & Azarlama / Bağırma & 5 & 6 & 26 \\
\hline & Performans notunu düşürme & 4 & 5 & \\
\hline & Dersi durdurma & 4 & 3 & \\
\hline & Sınıftan çkarma & 2 & 5 & \\
\hline & Öğrenci ile iletişime geçmeme/Öğrenciyi yok sayma & 2 & 2 & \\
\hline & Disiplin kuruluna sevk etme & 2 & 4 & \\
\hline & Fiziksel şiddet uygulama & 1 & 1 & \\
\hline & Ödev verme & - & 2 & \\
\hline & Toplam & 14 & 12 & \\
\hline \multirow[t]{5}{*}{ Dolaylı uyarı } & Öğrenciye yaklaşma / fiziksel yakınlık & 7 & 4 & 22 \\
\hline & Göz teması/göz kontağı kurma & 7 & 3 & \\
\hline & Jest ve mimikler kullanma/beden diliyle uyarı & 3 & 2 & \\
\hline & Ses tonunu değiştirme & 3 & 6 & \\
\hline & Toplam & 12 & 10 & \\
\hline Öğrenci ile iletişim & Öğrenci ile sınıf dışında birebir konuşma & 8 & 4 & 20 \\
\hline \multirow[t]{9}{*}{ kurma } & Empatik dinleme & 5 & 3 & \\
\hline & Nasihat etme/öğüt verme & 4 & 4 & \\
\hline & Davranışın sonuçlarıı açılama & 4 & - & \\
\hline & Davranışın gerekçelerini araştırma & 4 & 1 & \\
\hline & Sinıf içerisinde konuşma & 3 & 4 & \\
\hline & Uygun davranışa yönlendirme & 2 & 1 & \\
\hline & Sitemde bulunma & 2 & - & \\
\hline & Duygu ve düşüncelerini ifade ettirme & 1 & 2 & \\
\hline & Toplam & 11 & 9 & \\
\hline \multirow{10}{*}{$\begin{array}{l}\text { Farkındalık } \\
\text { oluşturma }\end{array}$} & Amaç belirlemelerine yardım etme & 5 & 1 & 20 \\
\hline & Derslerin önemine dikkat çekme & 4 & - & \\
\hline & Hayattaki başarı hikâyelerinden söz etme & 3 & 5 & \\
\hline & Olumlu örnekler vererek yol göstermeye çalışma & 3 & 3 & \\
\hline & Okuldaki hak ve sorumluluklarını bilmesini sağlama & 2 & - & \\
\hline & Tutarlı davranma & 1 & - & \\
\hline & Duyguların ve davranışlarını kontrol ederek model olma & 1 & - & \\
\hline & Okulun değerini ve görevini hissettirmeye çalışma & 1 & - & \\
\hline & İnsan hak ve özgürlüklerini koruyan ortamı yaratma & 1 & - & \\
\hline & Toplam & 8 & 8 & \\
\hline \multirow[t]{3}{*}{ Görmezden gelme } & Davranışı fark etme ancak herhangi bir uyarıda bulunmama & 4 & 6 & 10 \\
\hline & Hiçbir şey yapmama & 2 & 4 & \\
\hline & Toplam & 4 & 6 & \\
\hline \multirow{6}{*}{$\begin{array}{l}\text { Olumlu yaklaşım } \\
\text { tarzı/tutum }\end{array}$} & Öğrencileri atölye, staj yerlerinde vb. ziyaret etme & 4 & 1 & 8 \\
\hline & Öğrenciye değerli olduğunu hissettirme & 4 & 1 & \\
\hline & Öğrenciye saygı duyduğunu göstermeye çalışma & 2 & 1 & \\
\hline & Dürüst olma & 1 & - & \\
\hline & İyi niyetli olma & - & 1 & \\
\hline & Toplam & 6 & 2 & \\
\hline \multirow[t]{5}{*}{ İşbirliği yapma } & Yöneticilerle bilgi alışverişinde olma & 3 & 2 & 7 \\
\hline & Meslektaşlarının deneyimlerinden yararlanma & 3 & - & \\
\hline & Aileyi okula çağırma/bilgilendirme & 3 & 2 & \\
\hline & Diğer öğretmenlerle birlikte hareket etme & 1 & 1 & \\
\hline & Toplam & 5 & 2 & \\
\hline \multirow[t]{3}{*}{ Ödüllendirme } & Not yükseltme & 3 & 1 & 7 \\
\hline & Sembolik işaretler kullanma (+, yıldız vb.) & 2 & 2 & \\
\hline & Toplam & 4 & 3 & \\
\hline \multirow[t]{3}{*}{ Gözdağı verme } & Öğrencilere disiplin dilekçesi yazacağını söyleme & 4 & 2 & 6 \\
\hline & Resmiyet kazandırmadan tutanak tutma & 4 & 1 & \\
\hline & Toplam & 4 & 2 & \\
\hline
\end{tabular}


Öğrencide farkındalık oluşturma (f:8), olumlu yaklaşım tarzı/tutum (f:6), işbirliği yapma (f:5), görmezden gelme (f:4) ödüllendirme (f:4) ve gözdağı verme (f:4) bunları izleyen diğer yöntemler olmuştur. Ceza verme teması altında öne çıan kodlar azarlama/bağırma (f:5), performans notunu düşürme (f:4), dersi durdurma olmuştur. Azarlama/bağırma konusunda ÖĞRT14E görüşünü“...ses tonumu yükseltiyorum bağırıyorum aksi takdirde onlarn sesleri benim sesimi bastırıyor ve benim hâkimiyetimi elimden alıyorlar. Bunu önlemek için yaramaz olan birkaç öğrenciye ses tonumu yükselterek bağırıyorum durduramazsam onları sinf dişına çıkartıyorum, bir süre sonra tekrar geri alıyorum" sözleriyle ifade ederken dersi durdurma konusunda ÖĞRT16E görüşünü “...sınıf hâkimiyetimi kaybedince sinıfta ders anlatmayı bırakıyorum ve onlar sessiz oluncaya kadar bekliyorum. Gürültü yapmaya devam ederlerse de kimse ile iletişime geçmiyorum. Hepsinden nefret etmeye başlıyorum. Çok saygısızlar" ş̧eklinde açıklamıştır. Farklı iki öğretmenin açıklaması ise şöyledir:

“...her öğrencinin kendine göre uyarılması var herkese her yöntem uygulanmıyor. Kimine tatlı dille konuşma, kimine hiç konuşmama, ne dersen anlamiyor." ÖĞRT5E

“...her şeyi deniyorsun sabırlı oluyorsun ama durmuyorlar seni çileden çıkarıyorlar. Hayvan sesleri çıkarıyorlar. Tahtaya yazı yazmak için arkanı dönüyorsun garip sesler çıkariyorlar. Sende tespit edince bir tane vuruyorsun. Gözüm dönüyor artık. Pişman oluyorum ama." ÖĞRT10E

Disiplini sağlamak için dolaylı olarak öğrenciyi uyarma yöntemini kullanmayı tercih eden öğretmenlerin çoğunluğu bunu; öğrenciye yaklaşma/fiziksel yakınlık (f:7), göz teması/göz kontağı kurma (f:7) ve jest ve mimikler kullanma/beden diliyle uyarı (f:3) olarak açıklamışlardır. Örneğin ÖĞRT7K göz teması/göz kontağı kurma ile ilgili görüşünü“...sınıf içerisinde disiplin sorunu çok fazla birkaç öğrenci smıf düzenini bozuyorsa o öğrencilerle göz teması kuruyorum ve uzun bir süre onlara dikkatlice bakıyorum. Kızgın yüz ifadesi kurarak onlara duygularm belirtiyorum. Sonra sinıf fark edince herkes susuyor." şeklinde açıklarken, jest ve mimikler kullanma/beden diliyle uyarı yönteminde ÖĞRT13K görüşünü"...öğrenciye bağgrrnca bazı öğrenciler öğretmenler benimle ilgileniyor şeklinde algıllyor. Çünkü ailede öğrenci ile hiçbir iletişimde bulunmuyorlar. Bende bu durumu fark edince çoğu zaman kızgın yüz ifadesi ya da biraz sakin ol demek için sus işareti kullanıyorum. Böylece öğrencideki sorunlar biraz azalıyor" şeklinde açıklamıştır. 
Disiplin sorunları ile karşılaştığında öğrenciyle iletişim kurma yoluna giden öğretmenlerin çoğunluğu öğrencilerle sınıf dışında birebir konuşmayı (f:8) tercih ederken bunu sirasiyla empatik dinleme (f:5), nasihat etme/öğüt verme (f:4), davranış sonuçlarını açıklama (f:4) ve davranışın nedenlerini araştırma (f:4) yöntemleri izlemiştir. Örneğin ÖĞRT3K görüşünü“...bayan olunca öğrenci biraz seni güçsüz buluyor ve sana karşı gelme durumu daha fazla oluyor bende bazı öğrencilerde bunu fark edince onları sınıf dışına çıkarıp konuşuyorum o zaman korkuyorlar." sözleri ile açıklarken empatik dinleme ile ilgili ÖĞRT1E duyguların "...Öğrenci ile konuşmayı tercih ederim ilkönce. Çünkü edebiyatçıyım ben. Öğrencinin geldiği aile yapısını ve yaşammı anlayınca iyi bir dille onu ikna edebiliyorum. Öğrenci ile bă̆ kurmam daha iyi oluyor. Yani birbirimizi daha iyi anlayabiliyoruz" şeklinde ifade etmiştir. Davranışın nedenlerini araştırmanın önemli olduğunu ifade eden ÖĞRT8K düşüncesini “Öğrenciler çok sorunlu, her birinin bir hikâyesi var. Onlara kızıyorum ama hikâyelerinin öğrenince üzülüyorum. Bir keresinde bir velinin evini ziyaret etmiştim. Anne psikolojik hasta, baba kumarbaz çocuknasıl olabilir ki. "şeklinde ifade etmiştir. Disiplin sorunlarının sonlandırılmasında öğrencilerde farkındalık oluşturması gerektiğini ifade eden sekiz öğretmen bu süreçte öğrencilerin amaç belirlemesine yardım etme (f:5), hayattaki başarı hikâyelerinden söz etme (f:3), olumlu örnekler vererek yol göstermeye çalışma (f:3) ve okuldaki hak ve sorumlulukların bilmesini sağlama (f:2) yöntemlerini kullandıklarını belirtmişlerdir. Amaç belirleme konusunda ÖĞRT14E düşüncesini “Öğrencilerin çoğunun eğitimle ilgili amacı yok. Bu nedenle okulun öneminden ve gelecekte onlara ne gibi katkı să̆layacağından bahsediyorum. İnsanlarm başarn hikâyelerinden bahsediyorum. Hayata dair amaçlarının olmasımı sağlıyorum" şeklinde açıklarken, okuldaki hak ve sorumlulukların bilmesini sağlamada ÖĞRT9E görüşünü “Öncelikle insanların çoğu kendi haklarım ve sorumluluklarmı bilmeli ve ona göre davranmalı. Bende öğrencilerde bu durumun oluşmasını sağhıyorum. Hakkınızı ve karşı tarafin haklarım bilin ona göre davranın diyorum. Hatta dönemin ilk başında disiplin yönetmelĭgini okuyorum." şeklinde ifade etmiştir. Bu temada dikkat çeken diğer davranışlar ise tutarlı davranma, insan hak ve özgürlüklerini koruyan ortamı yaratma, okulun değerini, önemini ve görevini hissettirmeye çalışma ve duygularını ve davranışlarını kontrol ederek model olmadır. Tablo 3'te görüldüğü gibi öğrencilere karşı olumlu yaklaşım tarzı/tutum izlediğini belirten öğretmenler bu kapsamdaki davranışların; öğrencilerle atölye, staj yerleri vb. ziyaret etme, öğrenciye değerli olduğunu hissettirme, öğrenciye saygı duyma ve dürüst 
davranma olarak tanımlamışlardır. Öğrenciye değerli olduğunu hissettirme konusunda ÖĞRT6K görüşü “...ilk önce öğrencinin yanına gidiyorum ve aile yapısım öğrenmeye çalışıyorum. Örneğin annen baban să̆ mi, öz mü seni dövüyor mu gibi sorular soruyorum. Böylece öğrenci kendini değerli hissediyor, sonunda çocuk değerli olduğunu hissediyor, çözülüyor ve ona ulaşıyorum" şeklinde olmuştur.

Tablo 3'te öğrenciler açısından incelendiğinde öğrencilerin de, sinıfta disiplini sağlamada ceza verme (f:12), dolaylı uyarı yapma (f:10), iletişim kurma (f:9), farkındalık oluşturma (f:8) yöntemlerinin izlendiği konusunda görüş belirttiği görülmektedir. Öğrencilerin çoğunluğu azarlama/bağırma (f:6), performans notunu düşürme (f:5), sinıftan çıkarma (f:5), disiplin kuruluna sevk etme (f:4) cezalarının daha çok kullanıldığını vurgulamışlar ve şu şekilde açiklama yapmışlardır:

“...öğretmenimizle bazı arkadaşlar ağız dalaşına giriyor. Olaylar daha büyüyünce öğretmenimiz arkadaşımızı dışarıya çıkarıyor. Bazen attığı arkadaşın yanına birini de gönderiyor. Ama giden gelmiyor ki." ÖĞR3E9

“...öğretmen tüm yöntemleri kullanıyor ama baktı olmuyor tutanak tutuyor. Bu sefer herkes sus pus oluyor. Yoksa kuruldan ceza alırsak ailelerimiz bizi çok kötü yapar." ÖĞR7E10

“...öğretmen sürekli ses tonunu yükseltiyor bağırıyor... biz öğretmeni önemsemezsek çok takmıyoruz. İşe yarıyor mu kısmen” ÖĞR2K9

“...Öğretmenler kendi varlığını ortaya koymak yerine bizi notlarımızla sıkıştırıyorlar. Bu çoğu arkadaşımız için önemli onlar sınıf geçeyim yeter diyor" ÖĞR5K10

Disiplin sorunu yaratan öğrencilerin dolaylı olarak uyarıldığını ifade eden öğrenciler öğretmenlerin bunu; ses tonunu değiştirme (f:6), yaklaşıma/fiziksel yakınlık (f:4), göz teması/göz kontağı kurma (f:3) ve jest ve mimikler kullanma/beden diliyle uyarı (f:2) şeklinde yaptıklarını belirtmişlerdir. Örneğin ÖĞR4K9 öğretmenin ses tonunu değiştirme konusunda "...öğretmenimiz bazen anlamsız bir durumda ses tonunu yükseltiyor. $O$ an çok korkuyor ve irkiliyorum. Ama kendimize gelmemiz konusunda iyi oluyor. Hemde dikkat çekici oluyor." şeklinde açıklama yaparken, göz temasi/göz kontağ1 kurma konusunda ÖĞR12K11 duygularını“...çok sinirlendiklerinde kızgın ve dikkatli bakışlarından öğretmenimizi anlıyoruz. Ama bazı arkadaşlar ne yaptık ki diyerek karşı çıkıyorlar. Öğretmende daha da bağırarak onu bastırmaya çalışıyor" ş̧eklinde açıklamıştır. Öğretmenlerinin onlarla iletişim kurmaya 
çalışıldığını vurgulayan öğrenciler de görüşmelerin sınıf dışında birebir konuşma (f:4), nasihat etme/öğüt verme (f:4), sınıf içerisinde konuşma (f:4), ve empatik dinleme (f:3) olarak gerçekleştiğini belirtmişlerdir. Öğrencilerin yaptıkları açıklamalardan iki örnek şöyledir:

"Bizler sınıf içinde birbirimizden güç alıyoruz. Yalnız kalınca daha çok korkuyoruz. Bazı hocalarımız bunu fark etmiş hemen bizi ya dışarı alıyor ya da yanımıza gelip sakince konuşuyor."ÖĞR9E11

"Öğretmenlerimizin çoğu nasihat veriyor bize konuşuyor ama aynı şeyleri duyduğumuz için sıkılıyoruz...bizleri anlayarak dinlemeliler kendilerini anlatmalılar ki bizde onları algılayarak dinleyelim. Kendimizi ifade etmemize bazen yardımcı oluyorlar, bizleri bilseler ne kadar iyi olur." ÖĞR16K12

Öğretmenlerinin onlarda bir farkındalık oluşturmaya çalıştığını belirten öğrenciler öğretmenlerinin bunu daha çok kendi başarı hikâyelerinden söz ederek (f:5), olumlu örnekler vererek (f:3) ve amaç belirlemelerine yardım ederek yapmaya çalıştıklarını ifade etmişlerdir. Örneğin ÖĞR11K11 “...öğretmen dersi yarıda burakıp kendi üniversite yillarından bahsediyor bazende başka bilim insanlarının çalışmalarından anlatıyor. Çok etkilemese de arada bir işe yarıyor." sözleri ile ifade ederken olumlu örnekler verilmesi konusunda ÖĞR15K12 düşüncesini“... son smıf ö̆grencileriyiz ve anladık ki zamanımız saçma şeylerle boşa geçmiş bazı hocalarımız gelecek için plan yaptırmaya çalışırdı ama dinlemedik şu an uygulamaya çalışıyoruz." şeklinde açıklamıştır. Öğretmenlerin bazen sorun davranışları görmezden geldiğini (f:6) vurgulayan öğrencilerden biri olan ÖĞR9E11 ise görüşlerini “. . hocalarımı baktı ki bizler de ışık yok, bizi takmıyorlar. Bazen uyarmak gereği bile duymuyorlar. Bizde zaten böyle durumlar arıyoruz." şeklinde belirtmiştir.

\section{Disiplini Sağlamada En Sık Kullanılan ve Etkili Algılanan Yöntemlerle İlgili Bulgular}

Katılımclara yöneltilen ikinci soru disiplin sorunları karşısında en sık hangi yöntemlerin kullanıldığı olmuş, elde edilen bulgular Tablo 4 'te özetlenmiştir.

Tablo 4'te görüldüğü gibi öğretmenlerin çoğunluğu disiplini sağlamak için en sık cezalandırma (f:12) yöntemini kullandıklarını belirtmiş, bunu sırasıyla öğrenci ile iletişim kurma (f:11), olumlu yaklaşım tarzı/tutum (f:6) ve yönetimle işbirliği yapma izlemiştir. 
Tablo 4. Disiplin Sorunları Karşısında En Sık Kullanılan Yöntemler

\begin{tabular}{|c|c|c|c|c|}
\hline Tema & Kod & $\begin{array}{l}\text { Öğrt. } \\
\text { f }\end{array}$ & $\begin{array}{l}\text { Öğr. } \\
\text { f }\end{array}$ & $\begin{array}{l}\text { Top. } \\
\text { f }\end{array}$ \\
\hline \multirow[t]{4}{*}{ Cezalandırma } & Azarlama / Bağırma & 6 & 7 & 22 \\
\hline & Performans notunu düşürme vb. & 5 & 5 & \\
\hline & Dersi durdurma & 4 & 2 & \\
\hline & Toplam & 12 & 10 & \\
\hline \multirow[t]{5}{*}{ Öğrenci ile iletişim kurma } & $\begin{array}{l}\text { Öğrenci ile sınıf dışında birebir ko- } \\
\text { nuşma }\end{array}$ & 7 & 3 & 17 \\
\hline & Empatik dinleme & 4 & 3 & \\
\hline & Davranışın sonuçlarını açıklama & 3 & 1 & \\
\hline & Doğru davranışa yönlendirme & 2 & 1 & \\
\hline & Toplam & 11 & 6 & \\
\hline \multirow[t]{4}{*}{$\begin{array}{l}\text { Olumlu yaklaşım tarzı/tu- } \\
\text { tum }\end{array}$} & $\begin{array}{l}\text { Öğrencilerle ders dışında zaman } \\
\text { geçirme }\end{array}$ & 3 & 2 & 10 \\
\hline & Sevgi ile yaklaşma & 3 & 1 & \\
\hline & Başarı hikâyeleri anlatma vb. & 2 & 1 & \\
\hline & Toplam & 6 & 4 & \\
\hline \multirow[t]{3}{*}{ Yönetimle işbirliği yapma } & $\begin{array}{l}\text { Yöneticilerin deneyimlerinden } \\
\text { faydalanma }\end{array}$ & 3 & - & 5 \\
\hline & $\begin{array}{l}\text { Gerektiğinde durumu idareye sevk } \\
\text { etme }\end{array}$ & 3 & 2 & \\
\hline & Toplam & 3 & 2 & \\
\hline \multirow[t]{3}{*}{ Görmezden gelme } & Davranışı fark ettiğini belli etme & 3 & 1 & 4 \\
\hline & Herhangi bir uyarıda bulunmama & 3 & 1 & \\
\hline & Toplam & 3 & 1 & \\
\hline \multirow[t]{3}{*}{ Gözdağı verme } & $\begin{array}{l}\text { Resmiyet kazandırmadan tutanak } \\
\text { tutma }\end{array}$ & 3 & 1 & 4 \\
\hline & Disiplin dilekçesi yazacağını söyleme & 3 & 1 & \\
\hline & Toplam & 3 & 1 & \\
\hline
\end{tabular}

Cezalandırma teması altında öne çıkan yöntemler; azarlama/bağırma, performans notunu düşürme ve dersi durdurma yöntemleri olmuştur. Mecbur kaldıkları için cezalandırmaya gittiklerini belirten öğretmenlerden ÖĞRT18K"...̈̈ğrencilerle normal bir iletişim kurmaya çalş̧ıken öğrenci beni dinlemiyor ya da umursamıyor ama bağırnnca öğrenci beni daha dikkatle dinlemeye çalışıyor. Bunu araştırınca öğrencinin aile içerisindeki iletişimin böyle olduğunu gördüm” şeklinde duygularını ifade ederken, ÖĞRT12E “...öğrenci ancak elinden bir şey alınınca kendine geliyor zaten öğrenci üzerinde hiçbir etkimiz yok bize kalan sadece performans notları. Onu kullanarak disiplin sağlamaya çalışıyoruz. Sadece diploma için geldiklerinden notları elinden almınca zorlaşıyor durum" sözleriyle açıklamıştır.

Öğrenci ile iletişim kurmaya çalıştığını belirten öğretmenler; öğrenci ile sınıf dışında birebir konuşma (f:7) ve empatik dinleme (f:4) yöntemlerini kullanmayı daha çok tercih ettiklerini ifade etmişlerdir. Örneğin 
ÖĞRT14E‘nin bu konudaki görüşünü“en çok kullandığım yöntem öğrencilerin kendini ifade etmesini sağlamak bunun için öğrenci ile sınıf dışında birebir konuşuyorum böylece onu önemsediğimi anlyyor ve her şeyi rahatlkkla söylüyor. Sonrasinda daha sakin birisi oluyor" şeklinde açılamış, ÖĞRT16E ise görüşünü“...öğrencilerimizin her biri farklı çeorelerden geldi bu nedenle onları anlamamız lazım bunun için ilk olarak dinlemek ve kendimizi anlatmamı gerekir. Sürekli bağırmakla olmuyor iletişim kurmak gereklidir" sözleriyle belirtmiştir. Öğrencilerle ders dışında zaman geçirme (teneffüs, atölye vb.) (f:3), onlara sevgi ile yaklaşma (f:3) ve iyi niyet gösterisinde (f:3) bulunmayı sıklıkla ifade eden öğretmenlerden ikisinin yaptığı açılama şöyledir:

“...zaman buldukça çocuklarla sınıf dışında zaman geçirmeye çalışıyorum. Öğrenci böylece kendini değerli hissediyor ve önemsendiğini anlıyor. Tabii sınıf içerisinde bana karşı daha dikkatli davranıyor." ÖĞRT10E

"Bence her şey sevgi ile başlar. İnsanlar doğadaki tüm canlıları sevmeli ve bunu hissettirmeli, gerginlikler ancak bu şekilde son bulur. Gerginliğe gerginlikle karşılık vermek sorunları artırır." ÖĞRT6K

Öğretmenlerin disiplin sorunları ile baş etmede en çok kullandıkları diğer yöntemler; yönetimle işbirliği yapma, gözdağı verme ve görmezden gelme olmuştur.

Tablo 4'te görüldüğü gibi öğrenciler de öğretmenleriyle benzer görüş belirtmişler, disiplin sağlamada en sık cezalandırmaya başvurulduğunu ifade etmişlerdir (f:10). Örneğin öğrenciyi azarlama/bağırma konusunda ÖĞR4K9 görüşünü “...öğretmenlerimiz sevecenlikle yaklaşmaya çalışıyor ama onlarında sabrı bir yere kadar. Sonra kime denk gelirse azarlyyorlar. Başka çare bırakmıyorlar" şeklinde ifade ederken, performans notunu düşürülmesi ile ilgili ÖĞR6E10 duygularını "hepimizin temel isteği notların iyi olması her şey onun için, bunu bilen öğretmenlerimiz örneğin tarihçi performans notlarmı düşürmekle tehdit ediyor, ya da fazla puan veririm diyor" şeklinde açıklamıştır. Öğrenci ile iletişim kurma kapsamında kullanılan yöntemleri öğrenciler öğretmenlere kıyasla daha az nitelendirmişlerdir. ÖĞR9E11 empatik dinleme konusunda düşüncelerini "Beni dinleyen ve bana benim gözümle bakan biri ile konuşmak isterim. Edebiyatçımı bunu çok güzel yapıyor beni anlyyor bazen de bende onu anlyorum anlaşılmak güzel şey zaten her şey anlaşılmamaktan olmuyor mu" şeklinde ifade ederken, sınıf dışında birebir konuşma ile ilgili duygularını ÖĞR15K12 “...kendine güveni olmayan öğretmenler sinff içinde konuşurken, kendine güvenen öğretmenler arkadaşlarımızı sınıf dışına alarak birebir konuşuyor. Sımıf dışına çıkan 
arkadaşımı korkmaya başlar genelde ve mecburen yatışır" şeklinde açıklamıştır. Öğretmenlerinin onlarla ders dışında zaman geçirmesi (teneffüs, atölye vb.), sevgi ile yaklaşması ve iyi niyet göstermesine değinen az sayıda öğrenci görüşlerinden alıntılar aşağıda verilmiştir:

“...eğlenceli hocalarımız bazen teneffüslerde bizimle zaman geçiriyor şakalaşıyor sohbet ediyor. Böyle olunca kendimizi daha yakın hissediyoruz. Hem öğretmen hem arkadaş gibi bazen dozunu kaçırsak ta. Ders esnasında da saygı da duyuyoruz." ÖĞR1E9

“...sıcak bir gülümse veya sevimli bir yüz beni yumuşatıyor İngilizce” cimiz bunu sürekli yapıyor. Gergin olan öğretmenlerde bizde gergin oluyoruz. Biraz bizi anlasalar biraz gülümseseler her şey daha iyi olacak."ÖĞR7E10

Tablo 5'te, öğretmen ve öğrencilerin disiplini sağlamada daha etkili algıladıkları yöntemler gösterilmiştir.

Tablo 5. Disiplin Sağlamada Daha Etkili Algılanan Yöntemler

\begin{tabular}{llll}
\hline Kod & $\begin{array}{l}\text { Öğrt. } \\
\text { f }\end{array}$ & $\begin{array}{l}\text { Öğr. } \\
\text { f }\end{array}$ & $\begin{array}{l}\text { Top. } \\
\text { f }\end{array}$ \\
\hline Öğrenciyle bire-bir iletişime geçme & 9 & 8 & 17 \\
Empatik dinleme & 4 & 6 & 10 \\
Öğrencilerle ders dışında zaman geçirme & 3 & 5 & 8 \\
Sorun yaratan öğrencilerin notlarını düşürme & 3 & 3 & 6 \\
Yöneticilerle ve öğretmenlerle işbirliği yapma & 4 & 1 & 5 \\
Öğrenci davranışı ile ilgili tutanak yazma & 2 & 2 & 4 \\
Model alma/gösterme & 2 & 2 & 4 \\
Öğrenciyi ders dişına çıkarma & 2 & 1 & 3 \\
Öğrenciye değerli olduğunu hissettirme & 2 & 1 & 3 \\
Tutarlı davranma & 2 & - & 2 \\
\hline
\end{tabular}

Tablo 5 incelendiğinde öğretmenlerin disiplini sağlamada; öğrenciyle birebir iletişime geçme (f:9), empatik dinleme (f:4), yöneticilerle ve öğretmenlerle işbirliği (f:4), öğrencilerle ders dışında zaman geçirme ve not kırmayı (f:3) daha etkili buldukları görülmektedir. Tutanak yazma, model olma, öğrenciyi sınıftan dışarı çıkarma vb. ise etkili bulunmayan yöntemler arasındadır. Konuyla ilgili öğretmenlerin açıklamalarından örnekler aşağıda verilmiştir:

“... cezalar kısa süreli etkili oluyor. Ancak onlarla iletişime geçince disiplin sorunu davranış nispeten azalıyor. Onların yüreğine dokundukça onları anladıkça onlarda sana yaklaşıyor ve böylece sınıf ortamını düzeltebiliyorum" ÖĞRT8K 
“... öğrenciyi anlamak lazım, dersi çok güzel anlatmakla iş bitmiyor öğrencinin dersi benimsemesi lazım bunun için onları anlamalıyız. Kendi hislerimizi ve onların hislerini anlamalı ona göre hareket etmeliyiz. Öğrencileri tanıdıkça bazen onlar gibi bakıyorum. Aileler sorun, mahalle sorun, kaos ortaminda geliyorlar. İşlerinin ne kadar zor olduğunu anlıyorum." ÖĞRT17E

"Sınıf dışında baş başa konuşmak en etkilisi çünkü evlerinde onları dinleyen veya anlayan birileri yok. Sen onlarla iletişime geçince kendilerini değerli hissediyorlar. Ama bazende bu durumu abartarak şımarık hareketler yapıyorlar. Dengeyi kurmak önemli bu noktada" ÖĞRT6K

"Başa çıkamadığım şeyler olduğunda idareye bildiriyorum. İdarenin etkisi onların üzerinde daha fazla. İdare de hocam disiplin dilekçesi yaz deyince daha çok korkuyorlar. Bu yöntem çoğu zaman hoş olmasa da etkili oluyor. Bazen de diğer öğretmenlere öğrenci hakkında bilgi veriyorum ve bilgi verdiğimi öğrencilere de söylüyorum."ÖĞRT10E

Öğrencilerin disiplini sağlama konusunda daha etkili algıladıkları yöntemler öğretmenlerle benzer olmuş, iletişime geçme (f:8), empatik dinleme (f:6) ders dişında zaman geçirme (f:5) yöntemlerinde öğrenci frekansları daha yüksek olmuştur. Aşağıda öğrenci görüşlerinden alıntılar verilmiştir:

“...en etkilisi bizimle konuşmaları ama nasihat verir gibi değil, yani bizimle aynı yaşmış gibi genç gibi konuşmalarını isterim, sınıfta veya dışarıda" ÖĞR9E10

"bazen sinıfta bizlere hayal kurdurtuyorlar hatta öğretmen olmayı hayal ettiriyorlar ve aynı davranışlarla yüzleşmemizi sağlıyorlar. Bizde onlardan öğrenci gibi düşünmelerini istiyoruz. Çoğu zamanda hayalimizdeki üniversite için birlikte hayal kuruyoruz." ÖĞR15K12

“...ders dışında öğretmenlerimiz bazen bahçede dolaşıyor bazende nöbet tutuyorlar. Bizde yanlarına gidip "merhaba" diyoruz. Bizimle konuşunca öğretmenlerimiz çok hoşumuza gidiyor. Evde böyle bir ortamımız yok. Bazen öğretmenimiz sorun olan davranışı bize dışarıda gezerken söylüyor. Bizde onurlaniyoruz" ÖĞR7E10

\section{Öğretmenlerin Disiplin Sorunlarını Ele Alma/Yönetme Yeterlilikleriyle İlgili Bulgular}


Görüşmeler sırasında katılımcılardan konuyla ilgili görüşlerini açıklarken örnekler vermeleri istenmiş, öğretmenlerin kendilerini, öğrencilerin de öğretmenlerini yönetmede daha yeterli buldukları disiplin sorunları Tablo 6'da gösterilmiştir.

Tablo 6. Öğretmenlerin Disiplini Sağlama Yeterlilikleriyle İlgili Görüşler

\begin{tabular}{|c|c|c|c|c|}
\hline Tema & Kod & $\begin{array}{l}\text { Öğrt. } \\
\text { f }\end{array}$ & $\begin{array}{l}\text { Öğr. } \\
\mathrm{f}\end{array}$ & $\begin{array}{l}\text { Top. } \\
\text { f }\end{array}$ \\
\hline \multirow[t]{8}{*}{ Kabalık } & Saygisız davranışlar ( söz kesme, küçümseme) & 6 & 4 & 23 \\
\hline & Argo, küfürlü konuşma & 5 & 4 & \\
\hline & Lakap takma/ alay etme & 3 & 2 & \\
\hline & $\begin{array}{l}\text { Öğretmene karşı gelme (dinlememe, uyarılarını } \\
\text { dikkate almama vb.) }\end{array}$ & 3 & 2 & \\
\hline & Garip sesler çıkarma (Bağırma, çığlık atma vb.) & - & 2 & \\
\hline & İzin almadan başkalarının eşyalarını karıştırma & - & 2 & \\
\hline & Davranışını inkâr etme & - & 1 & \\
\hline & Toplam & 13 & 10 & \\
\hline \multirow[t]{6}{*}{ Derse karşı ilgisizlik } & Ders dışı şeylerle ilgilenme (cep telefonu) & 8 & 4 & 19 \\
\hline & Dersi dinlememe & 4 & 3 & \\
\hline & Gürültü yapma & 3 & 2 & \\
\hline & Ders esnasında uyuma & 3 & 2 & \\
\hline & Derse katılmama & - & 2 & \\
\hline & Toplam & 11 & 8 & \\
\hline \multirow[t]{6}{*}{ Ders akışını engelleme } & Derste sürekli konuşma & 6 & 4 & 16 \\
\hline & Ders esnasında yerini değiştirme & 4 & 3 & \\
\hline & Sınuf içerisinde bir şeyler yeme-içme & - & 2 & \\
\hline & Sınıftan izinsiz çıkma & - & 2 & \\
\hline & Dersle ilgisiz konularda sürekli soru sorma & - & 1 & \\
\hline & Toplam & 9 & 7 & \\
\hline \multirow[t]{5}{*}{ Zorbalık } & Kavga çıkarma/ kavga etme & 4 & 3 & 10 \\
\hline & Diğerlerini itme, sarsma, vurma & 2 & 2 & \\
\hline & Çeteleşme & - & 2 & \\
\hline & Güç gösterisinde bulunma & - & 1 & \\
\hline & Toplam & 6 & 4 & \\
\hline \multirow{4}{*}{$\begin{array}{l}\text { Sorumluluklarını yeri- } \\
\text { ne getirmeme }\end{array}$} & Derste not tutmama/ ödevlerini yapmama & 5 & 3 & 9 \\
\hline & Sorumluluk almama veya kaçınma & - & 2 & \\
\hline & $\begin{array}{l}\text { Okul malzemelerini derse getirmeme (kitap, } \\
\text { defter, kalem vb.) }\end{array}$ & 1 & 1 & \\
\hline & Toplam & 6 & 3 & \\
\hline \multirow{6}{*}{$\begin{array}{l}\text { Ortam/eşyalara zarar } \\
\text { verme }\end{array}$} & Sıraları- masaları çizme/karalama & 3 & 3 & 9 \\
\hline & Camları kırma & 2 & 3 & \\
\hline & Ders araç gereçlerini kırma/yırtma & 1 & 2 & \\
\hline & Okul duvarlarına yazı yazma & - & 2 & \\
\hline & Sınıfı kirletme (yerlere tükürme, çöp atma) & - & 1 & \\
\hline & Toplam & 5 & 4 & \\
\hline
\end{tabular}

Tablo 6 incelendiğinde öğretmenlerin çoğunluğunun kabalık (f:13), derse karşı ilgisizlik (f:11) ve ders akışını engelleme (f:9) davranışlarını ele almada kendini daha yeterli algıladığı görülmektedir. Öğretmenler kabalığı; söz 
kesme, küçümseme gibi saygısız davranışlar (f:6), argo, küfürlü konuşma (f:5), lakap takma/ alay etme (f:3) ve öğretmene karşı gelme (mesleğini küçümseme, dinlememe, karşı gelme vb.) (f:3) olarak tanımlamışlar, bu sorun karşısında izledikleri yöntemi öğrencilerle konuşmak olarak vurgulamışlardır. Davranışın etkileri konusunda bilgi vererek, empati kurmalarına yardım ederek, başarının çaba gerektirdiğini ve eğitimin bir şeyleri değiştirmedeki önemini fark ettirmeye çalışarak sorunu çözdüklerini ifade eden öğretmenlerin açıklamalarından örnekler aşağıda verilmiştir:

“...öğrenciler bazen bizi bazen arkadaşlarını küçümsüyorlar. Mesela çekingen, ürkek bir öğrenci varsa hemen onu pasifize edip dalga geçiyorlar. Onlarla konuşarak kişilere, olaylara veya durumlara farklı açılardan bakmalarını sağlıyorum." ÖĞRT3K

“...çok fazla küfürlü konuşuyorlar. Aslında normal bir durum bu çünkü öğrencinin yetiştiği mahalle ve aileler böylece olunca onlarda uyum sağlıyor. Bizlere garip geliyor ama durum bu. Burası meslek lisesi sonunda, bizde napalım onlara eğitimin amacından bahsediyorum diğerlerinden farklı olmamız gerektiğini ve hepimizin değişmesi gerektiğini anlatıyorum."ÖĞRT5E

“...öğretmene karşı olan saygısızlığı daha iyi önleyebiliyorum. Bizlerin verdiği emekleri üniversite yıllarımızı ve yaşadığımız zorlukları anlatıyorum. Hangi aşamalarda ne yaptık bahsediyorum onlara. Bizleri önemsemezlerse nelerle karşılaşabileceklerini ifade ediyorum." ÖĞRT8K

Derse karşı ilgisizlik sorunuyla ilgilenme konusunda kendini daha yeterli algilayan öğretmenler derse karşı ilgisizliği çoğunlukla ders dışı şeylerle ilgilenme (cep telefonu, kalem, kağıt vb.) (f:8), dersi dinlememe (f:4), gürültü yapma (f:3) ve ders esnasında uyuma (f:3) olarak tanımlamışlar, çoğunlukla uyarma, not kıracağını söyleme, konuşma, beden diliyle uyarma yoluna gittiklerini belirtmişlerdir. Açıklamalarından iki alıntı örneği şöyledir:

“...dersten sıkılınca kağıt kalem oynuyorlar, silgileri parçalayıp birbirlerine atıyorlar. Bende birkaç kişinin elinden bunları alıp sinirli bir şekilde çöpe atınca veya performans notları düşürecem deyince bırakıyorlar." ÖĞRT14E

“ öğrencinin amacı olmayınca ders dinlemiyor bir süre sonra uyuyor. Önceleri onlara çok ses çıkarmazdım. Sonra bu durum beni rahatsız etti. Bende uyuyan öğrencilerin yanına gelip uyandırıyorum ve bu davranışının neden beni rahatsız ettiğini anlatıyorum. Onlarda beni dinliyorlar uyanıorlar ama başka derslerde de uyuduklarını duydum." ÖĞRT18K 
Dersle ilgisi olmayan konularda sürekli sorular sorma/ konuşma ve ders esnasında yerini değiştirme olarak tanımladıkları ders akışını engelleyen davranışlarla baş etmede kendilerini yeterli algılayan öğretmenlerden ÖĞRT6K “...ders anlatırken gereksiz sorular soruyorlar dersle hiç alakası yok mesela çocuğunuz varmı? Onlara ilk olarak bunun dersle alakası olmadığını amaçlarının da bu olmadığım anlatıyorum. Bu tarz sorularm onları ilgilendirmediğini de söylüyorum." şeklinde açıklama yaparken, ders esnasında yerini değiştirme ile ilgili ÖĞRT8K görüşünü “... bir bakıyorum öğrenci bir yerden başka bir yere geçmiş, neymiş sıkılmış. Onu ilkönce yerine oturtuyorum ve yaptı̆̆ının yönetmelikte bile bir cezası olduğunu dikkatimin dağıldığını ve kuracağım cümleleri karıştırdığımı ifade ediyorum. Çoğunluğu olmasa da genellikle dediğimi dinliyorlar." şeklinde ifade etmiştir.

Tablo $6^{\prime}$ da görüldüğü gibi bazı öğretmenler sorumluluklarını yerine getirmeme (f:6), zorbalık (f:6) ve ortam/eşyalara zarar verme (f:5) davranışlarıyla ilgilenme konusunda kendilerini daha yeterli algilamaktadır. Sorumluluklarını yerine getirmeme davranışlarından olan derste not tutmama/ödev yapmama ve öğretim malzemelerinin eksikliği/okula getirmeme (kitap, defter, kalem vb.) davranışlarını sonlandırmada nasıl başarılı olduğunu ÖĞRT9E “Öğrencilere performans notu verirken ödev kontrolü yaparım ve defter kontrolü yaparım yapmayana eksi yapana artı veririm. Yada yapmayana bir şans daha veya yapanı örnek gösteririm. Böylece hem yapan gururlandırırım hemde yapmayana teşvik oluyor."şeklinde açıklamıştır. Ders araç gereçlerini kırma/yırtma(f:2) davranışlarını sonlandırmada kendini daha yeterli algılayan öğretmenlerden ÖĞRT11K bu duruma yönelik izlediği yöntemleri"Nasıl bir nesil anlamadık amaçsız öyle boş gezen tipler işte okula sadece geliyorlar var yazllmak için dersten haberleri yok tabi ki. Derste de sıkılıncada sataşıyorlar birbirine, straları falan çiziyorlar, defterlerini yırtıp küçük top yapıp birbirlerine atıyorlar. Bende onlara bunlarm ailelerin destekleri ile alındığın söylüyorum ama dinleyen yok. Bende defterlerinin tam olmasindan not veriyorum hatta bazen ailelerini çă̆ırı durumu anlatıyorum" şeklinde ifade etmiştir.

Tablo 6 öğrenciler açısından ve temalar bazında incelendiğinde öğrencilerin de öğretmenlerini kabalık (f:10), derse karşı ilgisizlik (f:8) ve ders akışını engelleme (f:7) davranışlarıyla ilgilenme konusunda daha yeterli algıladıkları, ancak bu kategoriler altında yer alan bazı davranışlarda öğretmenler kadar olumlu düşünmedikleri görülmektedir. Saygısız davranışlarla ilgili olarak ÖĞR3E9 görüşünü "Bence öğretmenler disiplin sorunların çok 
ciddiye almıyor ama kendilerine bir şey dediğimizde hemen kızıp bağırıyorlar. Onları küçümsediğimizi düşünüyorlar sanırım. Ama öyle bir niyetimiz yok. Uyarılarını dikkate alıyoruz hatta bizde ayıp olmasın diye arkadaşlarımızı bu konuda uyarıyoruz" şeklinde açıklarken, argo, küfürlü konuşmalar karşısında öğretmenlerin davranış biçimini ÖĞR6E10“ Sinıfta öğrenci küfür ederse direk yok yazllyor. Hocalar küfür duymak istemiyor. Küfür edince bize tiksinerek bakıyorlar bizde sus pus oturuyoruz." şeklinde açıklamıştır. Öğretmenlerinden farklı olarak öğrenciler sınıf içerisinde garip sesler çıkarma, izin almadan başkalarına eşyalarının karıştırma ve hatalarını inkâr etme davranışlarıyla ilgilenmede öğretmenlerinin yeterli olduğunu ifade etmişlerdir. Örneğin ÖĞR5K10 bu konuda“... arkadaşlar bazen garip sesler çıkarıyorlar mesela hayvan taklidi yapıyorlar öğretmende sinirleniyor. Ardından aynı hareketler simıfta yayılıyor öğretmende "hadi hep birlikte yapın diyor" ve şüphelendiklerini isim isim söylüyor o zaman herkes susuyor. Bazı öğretmenlerimizde insanlara yakışmayan davranışlar bunlar diyor durmamızı rica ediyor bizden. Bazılanda tüm sımıfı disipline veriyor" şeklinde görüş belirtmiştir.

Öğretmenlerin derse karşı ilgisiz davranışlarla baş etme konusunda yeterli olduğunu düşünen öğrencilerden ÖĞR10E11“...dersten sıkllnca bazen telefonlarla veya kă̆ıt kalem, stralara yazı yazma gibi şeylerle uğraşıyoruz. Öğretmen görünce uyarıyor buradaki amacınız unutmayın ve zorluklarla geldiğinizi hatırlayın diyor. Bende bırakıyorum ama bunu pek dinlemeyen arkadaşlar da var" şeklinde görüş ifade ederken, ÖĞR12K11 duyguların “...sinfin çoğu dersi dinlemiyor ama öğretmen yinede pes etmeden dersi anlatıyor, dinlemeyenlerin yanın gelip onları birebir uyarıyor yada onlara uzun süre dik dik bakıyor. Onlar da biraz toparlanıyor..." sözleriyle açıklamıştır. Ders akışını engelleyen davranışlarla ilgili olarak sürekli konuşma (f:4) ve ders esnasında oturma yerini değiştirme (f:3) davranışlarının yanı sıra farklı davranışlara da (sınıfta bir şeyler yeme içme, izinsiz sınıftan çıkma vb.) değinen öğrenciler bu sorunlarla baş etmede başarılı algıladıkları öğretmenlerinin davranışlarını şu şekilde örneklendirmişlerdir.

“...dersi dinlemeyenler sırf ders dağılsın diye öğretmene konuyu anlamadıklarını söylüyorlar ve öğretmen tekrar ederken dinlemiyorlar. Kendileri saçma örnekler veriyorlar aslında öğretmenle dalga geçiyorlar, öğretmenler de ya o öğrencilerle özel olarak ilgileniyor veya hiç umursamıyor. Bir süre sonra o arkadaşlarda bunu sonlandırıyor" ÖĞR5K10 
"Sınıf düzenini bozan veya dersi dinlemeyen kişileri öğretmenler kendi derslerinde en öne veya sessiz duracakları bir yere oturtuyor sonra sessiz kal, yoksa tutanak yazacam diyor. Onlarda sessizce oturuyor." ÖĞR7E10

“...mesela kimya öğretmeni bu konuda çok iyi baştan herşeyi açıkladı ve karşılığında neler olacağını da söyledi. Mesela geçen derste biri bisküvi yiyordu öğretmen önceden söylediği her şeyi bastıra bastıra hatırlattı istiyorsan ye dedi..." ÖĞR15E12

“...bazı arkadaşlar sınıfta çıkmak istiyor rahat durmuyorlar kıpır kıpırlar ne bilim garip yani. Hoca da izin vermiyor. Çık ozaman seni yok yazarım diyor ya da performans notunu düşürürüm diyor diğer öğrencilerde böylece sessizce derste kaliyorlar tabi bu çok uzun sürmüyor" ÖĞR1E9

Sorumluluklarını yerine getirmeme, zorbalık ve ortama/eşyalara zarar verme davranışlarında öğretmenlerini yeterli algılayan öğrencilerin sayısı nispeten daha az olmuş, öğrenciler bu kategoriler altında öğretmenlerinden farklı olarak sorumluluk almama veya kaçınma, çeteleşme ve güç gösterisinde bulunma, okul duvarlarına yazı yazma ve sınıfı kirletme davranışlarını da dile getirmişlerdir. Kavga çıarma/kavga etme davranışıla ilgili ÖĞR13E12 görüşünü“... aslında hiçbir yöntem etkili değil, öğretmenler bağırarak kendilerini tatmin ediyor sorun olan davranış o an bitiyor ama çoğumuz bunu tekrarlıyoruz. Bir şey söylemek gerekirse öğretmenler kavgaları ayırmada etkililer çünkü kavga edenler hemen disipline gidiyor." şeklinde açıklarken, sıraları-masaları çizme/karalama davranışının yönetiminde öğretmenini yeterli algılayan ÖĞR6E10 öğretmeninin davranış biçimini“...bir keresinde ders dinlemekten canım sıkılmıştı bende sıranın üzerine bir şeyler çiziyordum öğretmende beni gözlemliyormuş meğer. Birden yanıma geldi ve bana bu stralardaki çizikler yüzünden merkezi sinavlarda öğrenciler kodlama yaparken zorluk yaşıyorlar. Hatta optik formlarm delindiğinden haberin var mı dedi. Bende çok utandım bir daha da yapmadım" şeklinde tanımlamıştır. Okul duvarlarına yazı yazma (siyasi, cinsel içerikli...) davranışını ele alma konusunda öğretmenini yeterli bulan ÖĞR7E10 yaşadıklarını “...koridorda gezerken arkadaşın biri duvara siyasi bir partinin işaretini yapıyordu. Nöbetçi öğretmen o esnada arkadaşı gördü ve yanına yavaşça gelip bu senin işin değil. Senin işin çok iyi bir eğitim almak olmal, sen iyi işler yaparsan önce senin için sonra bizler için çok daha iyi bir şeyler olur dedi. $O$ günden sonra hem ben hemde arkadaş bazı şeyleri daha iyi anladik" sözleri ile anlatmıştır. Sorumluluk almaktan kaçınma davranışıyla baş etmede öğretmenleri yeterli algılayan öğrencilerden ÖĞR9E11 “...̇̇ngilizce' ci bir keresinde bana 
kızmak yerine ödev kontrollerini bana verdi. Bende daha fazla istek oldu, kendimi çok iyi hissettim, bana görev verilince. Çok hoşuma gidiyor artık. Mesela öğretmenler bana kızmak yerine bana görev verse hatta" şeklinde açıklama yapmıştır.

\section{Sınıfta Disiplini Sağlama Sürecinde Yaşanan Sorunlarla İlgili Bulgular}

Katılımcıların sınıfta disiplini sağlama sürecinde yaşanılan sorunlara yönelik açıklamalarından elde edilen tema ve kodlar Tablo 7' de verilmiştir.

Tablo 7. Disiplin Sorunlan İle Baş Etmede Yaşanılan Sorunlar

\begin{tabular}{|c|c|c|c|c|}
\hline Tema & Kod & $\begin{array}{l}\text { Öğrt. } \\
\text { f }\end{array}$ & $\begin{array}{l}\text { Öğr. } \\
\text { f }\end{array}$ & $\begin{array}{l}\text { Top. } \\
f\end{array}$ \\
\hline \multirow[t]{9}{*}{ Öğrencilerle İlgili } & Hataların kabullenmeme & 6 & 4 & 25 \\
\hline & Kendini iletişime kapama & 5 & 5 & \\
\hline & Davranışı kısa süre sonra tekrarlama & 4 & 4 & \\
\hline & $\begin{array}{l}\text { Olumsuz duyguların oluşması ( } \\
\text { kızgınlı,nefret) }\end{array}$ & 4 & 3 & \\
\hline & Ahlaki değerlerin giderek zayıflaması & 2 & 1 & \\
\hline & Bencilleşme & 2 & - & \\
\hline & Öğretim faaliyetlerine katılmama & 2 & 1 & \\
\hline & Yaşına uygun davranmama & 1 & - & \\
\hline & Toplam & 14 & 11 & \\
\hline \multirow{13}{*}{$\begin{array}{l}\text { Kendisiyle/ } \\
\text { Öğretmenlerle İlgili }\end{array}$} & İletişim kuramama/kurmama & 6 & 5 & 22 \\
\hline & Öğrencilere ulaşamama & 5 & 2 & \\
\hline & Sınıf hâkimiyetinin kaybolması & 5 & 4 & \\
\hline & Motivasyonunun düşmesi & 5 & 2 & \\
\hline & $\begin{array}{l}\text { Tükenmişlik hissetme (meslekten } \\
\text { soğuma) }\end{array}$ & 3 & 6 & \\
\hline & Hayal kırıklı̆̆ı yaşama & 2 & - & \\
\hline & Yetersizlik hissetme & 2 & 7 & \\
\hline & Olaylara duyarsızlaşma & 2 & - & \\
\hline & Diğer öğrencilere zaman ayıramama & 2 & 2 & \\
\hline & Daha sert davranmak zorunda kalma & 2 & 2 & \\
\hline & Öğretim faaliyetine devam edememe & 2 & 3 & \\
\hline & İç dünyasında çatışma/çelişki yaşama & 2 & - & \\
\hline & Toplam & 12 & 10 & \\
\hline \multirow[t]{3}{*}{ Sınıf Ortamıyla İlgili } & Davranışın sınıf geneline yayılması & 4 & 3 & 12 \\
\hline & Öğretim faaliyetlerin aksaması & 2 & 3 & \\
\hline & Toplam & 6 & 6 & \\
\hline \multirow[t]{3}{*}{ Velilerle İlgili } & Öğretmenlere kaba davranma & 2 & 3 & 5 \\
\hline & Çocuğunun hatasını kabul etmeme & 2 & 3 & \\
\hline & Toplam & 2 & 3 & \\
\hline
\end{tabular}

Tablo 7 incelendiğinde öğretmenlerin çoğunluğu disiplini sağlama sürecinde öğrencilerle (f:14) ve kendileriyle ilgili (f:12) sorunlara değinmişlerdir. Öğrencilerin yanlışlarını kabullenmemesi (f:6), kendilerini iletişime kapatmaları (f:5),davranışı kısa süre sonra tekrarlamaları (f:4), olumsuz duyguların oluşması (f:4) öğrenciyle ilgili vurgulanan sorunların başında gelmiştir. 
Öğrencilerin hatalarını kabullenmemesiyle ilgili ÖĞRT6K“...öğrenci hata yaptığının, davranışının sınıf ortamını bozdŭ̆unun farkında bile değil.Bu davranış sana uygun değil dediğinde ben hep böyleyim siz yanlış anladınız, arkadaşlarımla bir sorun olmadı diyorlar. Bende anlam veremiyorum" şeklinde açıklama yaparken, öğrencilerin kendini iletişime kapaması konusunda ÖĞRT5E görüşünü “...̈̈̆grenciyi uyardığımda onlarla iletişime geçemiyorum... Öğrencinin bizlerle iletişimi kapatmast olaylarn daha da büyümesine neden oluyor. Ne o beni ne ben onu anlıyorum" sözleriyle belirtmiştir. Öğretmenler disiplini sağlama sürecinde kendileriyle ilgili yaşadıkları sorunları daha çok öğrenciyle iletişim kuramama (f:6), öğrencilere ulaşamama (f:5), sınıf hâkimiyetinin kaybolması (f:5), motivasyonlarının azalması (f:5) olarak ifade etmişlerdir. Bunu mesleklerinde tükenmişlik hissetme (f:3) yetersizlik hissetme, olaylara duyarsızlaşma, diğer öğrencilere zaman ayıramama, daha sert davranmak zorunda kalma vb. izlemiştir. Aşağıda öğretmenlerin açıklamalarından örnek ifadeler verilmiştir.

"Bireysel anlamda balık baştan değil balık tamamen kokuyor. Ders içeriğinin hayattan kopuk olması, en verimli dönemde öğrencinin 20 metre kareye sokulması. Sınırsız özgürlüğü 20 metre kare ve sıraya oturtarak 1 metrekareye sokuyoruz. Bu nedenle iletişime geçmekte sıkıntı yaşıyorum. Öğrenci bu nedenle beni baştan algılamıyor. Onların gelişimsel özelliklerini ve değerlerini algılayamıyorum. Bu nedenle disiplin sorunu çözülmediği için iletişime geçmeye gerek yok diyorum çoğu zaman "ÖĞRT1E

“...bazı öğrencilere ulaşamıorum. Çünkü öğrenci aile içinde şiddetle büyümüş. Yani konuştuğumuz dil farklı. Yaptıkları yanlışları ısrarla yapmadıklarını ifade etmeleri onlara ulaşmamızda sıkıntı yaratmakta." ÖĞRT14E

“Her sınıfta birkaçöğrenci sınıf düzenini bozuyor belli okumak istemiyor. Onlarla uğraşırken bakmışım ki ders bitmiş. Diğer öğrencilerin hakkını yemiş oluyorum. Bu olaylarıda kontrol edemeyince kendimi garip hissediyorum. Bizimki çıkmaz bir nokta" ÖĞRT4K

"Yaşanan her şeye rağmen öğrenciler tutumlarını değiştirmiyor. Yeni yöntemler kullanmaya çalışsak da olmuyor. Motivem kayboldu bir şeyleri değiştirmek istemiyorum. Bana ne deyip dersimi anlatmaya devam ediyorum." ÖĞRT9E 
Öğretmenlerin disiplin sağlama sürecinde karşılaştıkları diğer sorunlar; sınıf ortamıyla ve velilerle yaşanılanlardır. Örneğin ortamla ilgili olarak davranışın sınıf geneline yayılmasını örnek veren ÖĞRT3K"...bir öğrenciyi sustururken bakmışı ki diğer öğrencilerin hepsi konuşmaya başlamış. Bu sefer hepsini susturmak daha da zorlaşıyor. Susturmak için daha çok bağırnca onlar tepki olarak devam ediyorlar" şeklinde açıklarken velilerle ilgili yaşadıkları sorunu ÖĞRT17E “...sorun yaşadığım öğrencinin velisini okula çağırıyorum ve olayı anlatryorum ama veli çocuğunu şımarık büyüttüğ̈̈ için ya da her şeyi kendine hak gördü̈̆̈̈ için çocuğunun hatasım kabul etmiyor. Bu sefer veliyi ikna etmeye çalışıyoruz. Kimi ikna edeceğiz bilmiyorum off" sözleriyle belirtmiştir.

Tablo 7 incelendiğinde öğrencilerin disiplin sürecinde yaşanan sorunlarla ilgili olarak öğretmenleriyle benzer düşüncelere sahip oldukları görülmektedir. Öğrenciler de disiplin sürecinde kendilerini iletişime kapattıklarını (f:5), hatalarını kabullenmediklerini (f:4), davranışlarının kısa bir süre sonra tekrarladıklarını (f:4) ifade ederek sorun yaşattıklarını ifade etmişlerdir. Örneğin kendini iletişime kapatma konusunda ÖĞR10E11“Öğretmenler bana dokunmasmlar da ne olursa olsun diyorlar. Böyle düşünen bir öğretmen bana ne katabilir ki bana kızınca bende takmiyorum, dinlemiyorum" sözleri ile açklarken, hatalarını kabul etmeme konusunda ÖĞR3E9 düşüncesini “Öğretmenler öncelikle değişime açık olmalı bizi anlamah veya anlatmalı, anlamadığım şeyde neyi kabul edebilirim ki?Sanırım farklı şeyleri konuşuyoruz onlarla" ş̧eklinde ifade etmiştir. Davranışı kısa sürede tekrar ettiğini ifade eden ÖĞR6E10 ise bu durumu“ Öğretmenlerimiz bağırarak bizleri susturuyor ama bizlerinde bazı ihtiyaçları olduğunu ve özelliklerimiz olduğunu bilmeli farkına varmalılar, bu anlaşılmayınca herkes bir dakika sonra eski halini alıyor." şeklinde ifade etmiştir.

Disiplini sağlama sürecinde öğretmenlerin yaşadıkları sorunların farkında oldukları görülen öğrenciler bu sorunları çoğunlukla yetersizlik (f:7), tükenmişlik (f:6), iletişim kuramama (f:5), sinıf hâkimiyetini kaybetme (f:4) olarak belirtmişlerdir. Ayrıca bazı öğrenciler öğretmenlerinin öğretim faaliyetine devam etme (f:3), öğrencilere ulaşma (f:2), motivasyonunu koruma (f:2) öğrencilere zaman ayırma (f:2) konusunda sorunlar yaşadıkların ifade etmişlerdir. Örneğin yetersizlik konusunda ÖĞR10E11 düşüncesini "Dersin ilk dakikalarnnda arkadaşlar öğretmenlere hocam ders ne? Konu ne? Bunlar ne işimize yarayacak? Diye soruyor, öğretmen ne kadar onlarla konuşmasa da öğrenciler rahat durmuyor o da off çekerek susuyor ne yapacă̆ın bilmezcesine... Hatta bazen siz kim ben kim, anlamıyorum diyen bile var" sözleri ile 
ifade ederken, öğretmenlerin tükenmişliği konusunda ÖĞR13E12 düşüncesini “...matematikçimiz bazen çaresizmiş gibi etrafa bakıyor. Hatta sonunda bize, sizin yüzünüzden çok sevdiğim mesleğimden soğudum dedi, umutsuzca bakıyor işte..."şeklinde açıklamıştır. Öğretmenlerin iletişim kuramaması/ kurmaması konusunda ÖĞR4K9 görüşünü“ Bazı öğretmenlerimizi çok yumuşak huylu, arkadaşlar öğretmenin sımıf içinde çok konuşmasına imkân vermiyorlar. Bence öğrenciler çok fazla değişmek istemiyorlar. Kendi hallerinden memnunlar. Durum bu olunca öğretmenlerimiz çokta takmıyorlar bizi" sözleriyle belirtmiştir. Öğrencilerin sinıf ortamıla (f:6) ve velilerle (f:3) yaşadıkları sorunlarla ilgili olarak açıklama yapan öğrencilerden ikisinin görüşünden alıntılar şöyledir:

“...kimya öğretmenimiz bazen baş edemiyor bizimle o arada arkadaşlar kâğıttan uçak atıyor kâğıdı top yapıp atıyor. Yazı yazmak isteyen arkadaşları tembeller engellemeye çalışıyor. Sadece öğretmenin ders anlatması engellenmiyor dersi dinlemek isteyene bile engel oluyorlar" ÖĞR15K12

“....arkadaşlarımızın çoğu olayları ailelerine yanlı anlatıyor. Öğretmeni suçlar nitelikte, aileler okula gelince öğretmenin üzerine çullanıyorlar resmen. İdare olmasa olaylar daha da büyüyecek, idare bazen çok kurtarıcı oluyor." ÖĞR10E11

\section{Disiplin Sorunlarını Önleme ve Kalıcı Çözümler Üretmeye Yönelik Görüşlerle İlgili Bulgular}

Görüşmeler sırasında öğretmen ve öğrencilere son olarak "disiplin sorunlarını önlemek/kalıcı çözümler üretmek için nasıl bir yol izlenmelidir? /etkili disiplin nasıl sağlanabilir?" sorusu yöneltilmiş ve elde edilen bulgular Tablo 8 ' de özetlenmiştir. 
Tablo 8. Disiplin Sorunların Önleme/Kalıcı Çözümler Üretmeye Yönelik Görüşler

\begin{tabular}{|c|c|c|c|c|}
\hline Tema & Kod & $\begin{array}{l}\text { Öğrt. } \\
\mathrm{f}\end{array}$ & $\begin{array}{l}\text { Öğr. } \\
\text { f }\end{array}$ & $\begin{array}{l}\text { Top. } \\
\mathrm{f}\end{array}$ \\
\hline \multirow{20}{*}{$\begin{array}{l}\text { Öğretmenlerin } \\
\text { değişimi/gelişimi }\end{array}$} & Yönetici, öğretmenler, veli ve rehberlik servisiyle işbirliği içinde olma & 7 & 5 & 32 \\
\hline & Mesleki gelişimini sağlama & 4 & 7 & \\
\hline & Öğrencilerin farkındalı̆ı̆ıı arttırma & 4 & 5 & \\
\hline & Öğrencilere karşı olumlu tutum ve davranışlar sergileme & 4 & 5 & \\
\hline & Ceza verme & 4 & 2 & \\
\hline & Zenginleștirilmiş öğretim ortamı hazırlama & 4 & 4 & \\
\hline & Davranışın nedenini araştırma & 3 & 7 & \\
\hline & Aile hakkında bilgi toplama & 3 & - & \\
\hline & Öğrenci ile etkili iletişim kurma & 3 & 6 & \\
\hline & Eleștiriye açık olma & 2 & - & \\
\hline & Umutlu/ hevesli olma & 2 & - & \\
\hline & Gerektiğinde öğrenciyi disipline gönderme & 1 & 2 & \\
\hline & Ödüllendirme yapma & 1 & - & \\
\hline & Davranışın sonucunu açıklama & 1 & - & \\
\hline & Ev ziyaretleri yapma & 1 & 2 & \\
\hline & Öğrencilere ahlaki değerleri öğretme & 1 & - & \\
\hline & Öğrencilerin yapabileceklerine inanma & - & 4 & \\
\hline & Geçmişi ve şimdiyi kıyaslamama & - & 3 & \\
\hline & Disiplin kavramını öğretme & - & 2 & \\
\hline & Teknolojiyi daha iyi kullanma & - & 1 & \\
\hline \multirow{14}{*}{$\begin{array}{l}\text { Okul ortamında } \\
\text { düzenlemeler }\end{array}$} & Sosyal alanların artırılması & 5 & 2 & 19 \\
\hline & $\begin{array}{l}\text { Öğretmen ve öğrenci iletişimini arttırmaya yönelik sohbet odaları oluşturul- } \\
\text { ması }\end{array}$ & 4 & - & \\
\hline & Okulun fizik koşullarını iyileştirme & 3 & 3 & \\
\hline & Okul kurallarının karalılıkla uygulanması & 3 & 3 & \\
\hline & Öğretmenlerin mesleki gelişimine yönelik çalışmalar yapılması & 2 & 1 & \\
\hline & Haftalık ders çizelgelerinin derslerin özelliğine uygun olması & 2 & 4 & \\
\hline & Kılık kıyafet yönetmeliğinin uygulanması & 2 & 1 & \\
\hline & Disiplin kurulunda ailenin aktif rol alması & 1 & - & \\
\hline & Veli toplantilarını artırma & 1 & - & \\
\hline & Okul- çevre ilişkilerini güçlendirerek okulun sayginlığını arttırma & 1 & - & \\
\hline & Okulun büyüklüğüne göre rehber öğretmen sayısının artırılması & 1 & 2 & \\
\hline & Dilek ve şikâyet kutusu oluşturulması & - & 3 & \\
\hline & Disiplin cezaları arasinda para cezasının olması & - & 2 & \\
\hline & Öğrenci memnuniyeti ile ilgili anket yapılması & - & 3 & \\
\hline \multirow{10}{*}{$\begin{array}{l}\text { Yasa ve yönet- } \\
\text { meliklerde } \\
\text { düzenlemeler }\end{array}$} & $\begin{array}{l}\text { Eğitim programlarının işlevsel olması (programların hayata yakın olması, } \\
\text { ders kitapların güncel konuları içermesi vb.) }\end{array}$ & 6 & 2 & 17 \\
\hline & Karnelerde akademik başarının yanında sosyal becerilere de yer verilmesi & 4 & - & \\
\hline & Öğretmenlik mesleğiyle ilgili düzenlemeler yapılması (saygınlı̆ıııı arttırma) & 3 & - & \\
\hline & Yönetmeliklerin daha uygulanabilir olması & 3 & - & \\
\hline & Disiplin yönetmeliğinin düzenlenmesi & 3 & - & \\
\hline & Teknolojinin eğitimde daha işlevsel kullanılması & 2 & 2 & \\
\hline & Öğretmen yetiştirme programlarının revizyonu (dersler, formasyon vb.) & 2 & - & \\
\hline & Merkezi sınavların kaldırılması & 1 & - & \\
\hline & Her okulda okul psikologlarının da bulunması & 1 & - & \\
\hline & Ders sayısınin azaltılması & - & 4 & \\
\hline \multirow{3}{*}{$\begin{array}{l}\text { Öğrencileri } \\
\text { geliştirme }\end{array}$} & Kişisel gelişimlerini sağlama (sinema, tiyatro, kitap okuma etkinlikleri vb.) & 8 & 1 & 14 \\
\hline & Seminer düzenleme ( ergenlik, insan ilişkileri vb.) & 4 & 3 & \\
\hline & Öğrencilere okulun karar organizasyonlarında görev verme & - & 2 & \\
\hline \multirow{3}{*}{$\begin{array}{l}\text { Veli gelişimini } \\
\text { sağlama }\end{array}$} & Seminerler düzenleme (ergenlik, iletişim, kadın-erkek ilişkisi vb.) & 4 & 2 & 8 \\
\hline & Okulda aktif görevler verme & 1 & 2 & \\
\hline & Okulu tanıtma (programı, kuralları, işleyişi vb.) & 1 & - & \\
\hline \multirow{2}{*}{$\begin{array}{l}\text { Medya } \\
\text { desteğinin } \\
\text { sağlanması }\end{array}$} & Olumsuz örnekler içeren yayınların yasaklanması (film,dizi, vb.) & 2 & - & 3 \\
\hline & Öğretmenliğin saygınlığını itibarını vurgulayan yayınların artırılması & 1 & - & \\
\hline
\end{tabular}


Tablo 8 incelendiğinde öğretmenlerin disiplin sorunlarını önleme ve kalıc çözümler üretmek için öncelikle öğretmenlerde bir değişim/gelişme (f:16) daha sonra okul ortamında düzenlemeleri (f:11) vurguladıkları görülmektedir. Bunu yasa ve yönetmeliklerde düzenlemeler, (f:10), öğrencileri geliştirme (f:9), velilerin gelişimini sağlama (f:4) ve medya desteği (f:3) izlemiştir. Öğretmenlerde değişim teması altında daha çok işbirliği yapma (f:7), mesleki gelişimini sağlama (f:4), öğrencilerde farkındalık oluşturma (f:4), öğrencilere karşı olumlu tutum ve davranışlar içinde olma (f:4), gerektiğinde ceza verme (f:4) ve zenginleştirilmiş öğretim ortamı hazırlama olmuştur. Bazı öğretmenler bu kapsamda eleştiriye açık olma, öğretmenin umutlu/ hevesli olması, gerektiğinde öğrenciyi disipline gönderme, ödüllendirme, davranışın sonucunu açıklama, ev ziyaretleri yapma ve çocuklar ahlaki değerleri öğretme üzerinde durmuşlardır. Mesleki gelişim sağlama ile ilgili ÖĞRT14E görüşünü “...Öğretmenler kendilerini hem meslek hemde pedagojik olarak yetiştirmeli, Öğretmen sinufa girerken daha sevimli ve güler yüzle girmeli, biraz psikoloji okuyabilirler" şeklinde açıklarken, gerektiğinde ceza verme konusunda ÖĞR15E görüşünü“...cezalar olmal ama kişisel özgürlük ve haklara zarar verilmemeli ve caydırıcı özellikte olmahdır. Şuan ki cezalar pek caydırıcı değil" şeklinde ifade etmiştir. Davranışın nedenlerini araştırma konusunda ÖĞRT6K düşüncelerini “...öğretmenler özellikle kararlı olmal. Benzer davranışa benzer tepkiler verilmeli. Ama bunun için öncelikle öğrenci davranışlarının nedenleri araştırmal. Önce sormak gerekir neden bu davranışı yaptı diye. Birçok sebep var. Benim bu konuda hoş olmayan bir yaşantım var. Çocuklar normal olmayan aile yaşantılar ile mücadele etmekte" şeklinde ifade etmiştir.

Etkili disiplin için okul ortamında düzenlemelere ihtiyaç olduğunu düşünen öğretmenlerin çoğunluğu okulda sosyal alanların artırılmasını (f:5) vurgulamış, bunu öğretmen ve öğrenci iletişimini sağlayan sohbet odaları oluşturma (f:4), okulun fiziki koşullarını iyileştirme (f:3) ve kuralları kararlılıkla uygulama (f:3) izlemiştir. Örneğin okulda sosyal alanların artırılması konusunda ÖĞRT3K düşüncesini “...iletişim ve sosyal alanlar artırllmalı öğrenciler kendilerini keşfetmeliler. Öğrencilerin dünyasına girersek daha etkili çözümler üretiriz. Mesela idareciler okulda etkinlikler, kermesler, yarışmalar düzenleyerek ve onlarla beraber görevler alarak etkileşimi artırabiliriz. Böylece onlarda neler yapması gerektiğini öğrenirler" sözleriyle açıklama yapmıştır. Okulun fiziki koşullarının iyi olmadığını ve öğrencilere ilgi çekici gelmediğini ifade eden 
ÖĞRT12E bu durumu “...okullarımız çok bakımsız sadece soğuk bir bina, ilkokulda renkli ve çekici olan binalar nedense liselerde çok renksiz...okulun dış görünüşü ve fiziki şartları iyi olmalı. Öğrenciler aradığı her şeyi bulabilmeli okulda." sözleriyle belirtmiş ÖĞRT17E ise okul kurallarının kararlılıkla uygulanması ve işbirliği yapılması gerektiğini “...bizim verdiğimiz kararlar okul idaresi desteklemeli ve kararllıkla uygulamalı öğrenciye göre değiştirmemeli. Bu okulun kendini iyi bir şekilde reklam etmesini ve okula yönelik algısını geliştirir. Herkese göre kurallar farklı uygulanırsa işle çok karışır" şeklinde ifade etmiştir. Haftalık ders çizelgelerinin derslerin özelliğine uygun olması, kılık kıyafet yönetmeliğinin uygulanması, veli toplantılarını arttırma, okulun büyüklügüne göre rehber öğretmen sayılarının arttırılması okul ortamıyla ilgili dile getirilen diğer görüşler arasında yer almıştır.

Yasa ve yönetmeliklerde düzenlemeler teması altında; eğitim programlarını işlevselliğini artırma (f:6), karnelerde akademik başarının yanında sosyal becerilere de yer verme (f:4), öğretmenlik mesleğinde düzenlemeler yapma (f:3), yönetmeliklerin daha uygulanabilir olması (f:3) ve disiplin yönetmeliğinin düzenlenmesi (f:3) öne çıkmıştır. Eğitim programlarının gerçek yaşamdan kopukluğunu dile getiren ÖĞRT13K görüşünü “...öğrenci 11.sinıfa geldiği zaman eğitim sistemini çözüyor ve günlük yaşamla bă̆lantılı olmadiğını tamamen fark ediyor. Bundan sonra kopuş başlıyor. Öncelikle eğitim öğrenci yaşamına hitap etmeli, işlevsel olmalı" şeklinde ifade ederken, karnelerde akademik başarının yanında sosyal becerilere de yer vermeye yönelik ÖĞRT13K "En önemlisi, karnede davranış notu olmalı. Bu notu zayıf olanın sinıfta kalma gibi bir şartı getirmeli, bu not diğer notlardan önce gelmeli. Birçok gelişmiş toplum bunu yapıyor." şeklinde açıklama yapmıştır. Öğretmenlik mesleğiyle ilgili düzenlemeler yapma, saygınlı̆̆ını arttırma ile ilgili olarak ÖĞRT2K düşüncesini “...eskiden Köy Enstitülerinde olduğu gibi öğretmenler beklenti ve mücadelelerini bırakmamah. MEB öğretmenlere haklarmı vermeli ve motive etmeli. Öğretmenin can güvenliğini sağlamal. Öğrenciler her şeyi ihbar ediyor bu engellenmeli. Öğretmenlere hakları verilince her şey sona erer."şeklinde açıklamıştır. Öğretmen yetiştirme programlarının revizyonu (dersler, formasyon vb.) üzerinde duran öğretmenlerden ÖĞRT12E ise düşüncesini“...eğgitim fakültelerinde okutulan derslerin içeriği güncellenmeli ve hepsi uygulamal olmah. Sahada çalışmalar yapmah eğitim fakültesi öğrencileri okulu ve öğrencileri daha yakında tanımalı. Stajlara daha fazla yer verilmeli. Birde toplum içinde duruşumuzla sayginlığımızı artırmahyız. Bu da hep birlikte olur" şeklinde ifade etmiştir. 
Öğrenci ve velilerin gelişimini sağlama temaları altında; öğrencilerde kişisel gelişim sağlama, öğrenciler ve velileri geliştirici, bilgilendirici seminerler verme, velilere okulda aktif görevler verme üzerinde durulmuştur. Medyanın da destek olması gerektiğini belirten öğretmenler olumsuz örnekler içeren yayınların yasaklanması gerektiğini vurgulamışlardır. Bu konudaki öğretmen görüşlerinden alıntılar aşağıda verilmiştir:

“Öğrenciler kendilerini geliştirmeli sadece ders kitabı ile olmaz sadece iyi öğretmekle olmaz onları yeni ve farklı kitaplarla karşlaştırmalıyız." ÖĞRT1E

"Öğrencinin sorununu anlamak için veli ile iletişime geçilmeli ve onlara gerekli bilgiler verilmeli. Bazı veliler gerçekten çok cahil kendi kafasının dikine gidiyor. Okulu onlara tanıtmalıyı" ÖĞRT10E

"Saçma sapan okul dizileri yayından kaldırılmalı. Reyting uğruna okullar gezme yeri gibi gösteriliyor, konu hep aşk üstüne, hiç ders çalışan bir öğrenci yok dizide. Öğretmenin itibarı da yok ediliyor. Okulu ve öğretmenlerin öven, önemseyen okul dizileri, filmleri yapılabilir." ÖĞRT14E

Tablo 8'de görüldüğü gibi disiplin sorunlarını önleme/ kalıcı çözümler için öğrencilerin tamamı (f:16) öğretmenlerin gelişimi/değişimini vurgulayarak öğretmenleri ile hem fikir olmuşlar, daha çok öğretmenlerin mesleki gelişim sağlamaları (f:7), öğrenci davranışlarının nedenini araştırmaları (f:7), öğrencilerle etkili iletişim kurulması (f:6), öğrencilerde farkındalık oluşturma (f:5) ve öğrencilere karşı olumlu tutum ve davranışlar göstermeleri (f:5) üzerinde durmuşlardır. Örneğin ÖĞR2K9 öğretmenlerin mesleki gelişim sağlamasıyla ilgili görüşünü “...teknoloji çağındayız ve birçok öğretmenin yaşı nedeniyle teknolojiyi bilmiyor. Cep telefonunu bile zor kullanıyorlar. Teknolojiyi öğrenerek kendilerini geliştirseler bunu da derste uygulasalar." Sözleriyle ifade ederken yaptıkları davranışların nedeninin araştırılması gerektiğini belirten ÖĞR9E11 “...öğretmenler önce bizi anlamalılar okullara tam hazırliklı olarak gelmiyoruz. Mesela ben bisikletle okula geliyorum. Illk ders yorgun oluyorum.Öğretmen uyuyunca da beni azarlıyor. Önce bir sormalı neden diye?" şeklinde açıklama yapmıştır. Öğrenciler ayrıca öğretmenlerinde farklı olarak öğretmenlerin öğrencilerin yapabileceklerine inanmaları, geçmiş ve şimdiyi kıyaslamamaları, öğrencilere disiplin kavramını öğretmeleri ve teknolojiyi daha iyi kullanabilmeleri yönünde görüş belirtmişlerdir. Aşağıda bununla ilgili iki örnek verilmiştir. 
“...bizim bir şeyler yapabileceğimize inanmalılar, bazı sorunlarda bizlerde karar vermeliyiz söz sahibi olmalıyız. Yapabiliriz bize aciz gibi bakmalarına gerek yok." ÖĞR5K10

“...disiplinli olun diyorlar bende oluyorum ama kabul etmiyorlar. Sadece susmak $\mathrm{m}$ disiplin anlamadım ya da ceza mı? Bunda farklılık var ve bende anlamiyorum. O zaman öğretsinler böylece sorunlar oluşmaz." ÖĞR14E12

Okulda düzenlemeler yapılması görüşlerine başvurulan öğrencilerin yarısının vurguladığı bir diğer disiplini sağlama yöntemi olmuştur. Haftalık ders çizelgelerini derslerin özelliğini dikkate alarak yapılması (f:4), kuralların karalılıkla uygulanması (f:3) okulun fizik koşullarını iyileştirilmesiyle (f:3) ilgili görüş belirterek öğretmenleriyle benzer açıklamalar yapan öğrenciler farklı olarak dilek ve şikâyet kutusu oluşturma (f:3), öğrenci memnuniyeti ile ilgili anketler yapma (f:3) ve disiplin cezalarının para cezası şeklinde olması gibi farklı (f:2) düşüncelerinden bahsetmişlerdir. Örneğin ÖĞR5K9 haftalık ders çizelgelerinin hazırlanması ile ilgili düşüncesini “...ders sayımız çok fazla, akşam beş gibi okuldan çıkıyoruz ve yoruluyoruz. Bazen de sayısal dersler ayn gün üst üste gelince daha çok yoruluyoruz. Ders programlarmı z daha iyi düzenlenmeli" şeklinde açıklarken kuralların kararlılıkla uygulanmasıyla ilgili ÖĞR8E10 düşüncesini“...hiçbir okulda öğrenciye göre muamele olmamah herkese ayn $k u$ rarlar uygulanmalı ve ceza neyse o çekilmelidir. Müdür, müdür yardımcllar biraz sert olmalı ve kurallarn hemen ve eşit bir şekilde uygulamalılar." şeklinde ifade etmiştir. Dilek ve şikâyet kutusu oluşturma konusunda ÖĞR13E12 görüşlerini “...arkadaşlarn ziyarete gittiğimde okullarmda dilek ve şikâyet kutusunu görüyorum çok hoşuma gitti. Bizim okulda da olsa herkes neler neler yazar. En azından okulu önemsendiğimiz belli olur. Duygularımızı öğrenince belki okul idareside bir şeyler yapar"sözleriyle belirtmiş, öğrenci memnuniyeti ile ilgili anket düzenlenmesi ile ilgili ÖĞR3E9 görüşünü “... bizim dünyamızı anlamaları lazım bunuda ancak bizlere sorarak bulurlar, tek tek soramazlar ama formlarla bunu belirleyebilirler. Mesela bazen özgeçmiş istiyorlar bunun gibi olabilir" şeklinde ifade etmiştir. Disiplin cezalarının para cezası şeklinde olması konusunda ÖĞR7E10 ise düşüncesini“... bu ülkede her şey para ile ödeniyor bizde ceza alınca para verelim..." şeklinde belirtmiştir.

Eğitimle ilgili yasa ve yönetmeliklerle disiplin sorunlarının önlenebileceğini düşünen öğrenciler ders sayılarının azaltılması (f:2), eğitim programlarının günlük yaşamla ilişkili olmasını (f:2), teknolojinin eğitimde daha işlevsel kullanılmasını (f:2) vurgulamışlardır. Örneğin ders sayılarının 
azaltılması gerektiğini ifade eden ÖĞR5K10 görüşünü "ders sayımız çok fazla sabahtan akşama kadar ders sıkllyyoruz özellikle son iki saat çekilmez oluyor" şeklinde ifade ederken, eğitim programlarılla ilgili ÖĞR10E11 düşüncesini "Dersler aynı, dersin işlenişi hep aynı, yazdır, soru çöz devam et. Deney yok, görsellik yok doğal olarak sıklliyoruz. Sürekli ayn yöntemler, bilgiler günlük, yaşamla bağlantıl olsa iyi olur. Herşey tahtada problem çözme" şeklinde açıklamada bulunmuştur. Teknolojinin eğitimde daha işlevsel kullanılması konusunda ise ÖĞR13E12 açıklamasını “...teknoloji hızla gelişiyor ama biz hala kalemlerle soru çözüyoruz. Bazen internete bakıyorum çok değişik aletlerle ders anlatıyor yabancı öğretmenler. Bir keresinde bir öğretmenin tabletinde üç boyutlu bir cisim tabletin dışında gibi göründü keşke bizde de böyle olsa. Akıll tahtalar var ama oda televizyon gibi"şeklinde yapmıştır. Medya ile ilgili görüş belirtmeyen öğrenciler kendilerine ve velilere yönelik görüşlerinde öğretmenleri ile benzer açıklamalarda bulunmuşlardır. Bu temalarda öğrencilerin; kişisel gelişim sağlaması, seminer alması, okulun karar organizasyonlarında görev alması ve velilere; seminer verme ve okulda aktif görevler verme durumlarına değinmişlerdir. Bu konudaki görüşlerden iki örnek aşağıdaki gibidir.

“...okullarda öğrencilerden okul temsilcisi seçiliyor ama bunların hepsi boş, her şeyi idare belirliyor. Öğrenci temsilcileri daha aktif olmalı hatta disiplin kurulunda bile görev almalı. Olaylara bizim gözümüzle bakılmalı." ÖĞR12K11

“...seminerler versinler velilerimize, tanısınlar, tanitsınlar, kimiz neyiz, hep suçlayacaklarına yönlendirsinler." ÖĞR16K12

\section{Tartışma, Sonuç ve Öneriler}

Araştırma sonucunda katılımcların çoğunluğunun disiplin sorunları karşısında ceza verme ve uyarma yöntemlerinin uygulandığı konusunda hem fikir oldukları görülmüş, azarlama,/bağırma, performans notunu düşürme ve dersi durdurma ise en sık verilen cezalar olmuştur. Öğretmenlere disiplin sağlamada en sık kullanılan yöntemler cezalandırma ve öğrenci ile iletişim kurma; öğrencilere göre ise cezalandırmadır. İlgili literatür incelendiğinde ortaöğretimde disiplinin benzer yöntemlerle sağlandığını gösteren çalışmalara ulaşılmıştır (Atıcı ve Çekici, 2009; Erzurum ve Kır, 2011; Maya, 2004; Raby, 2012; Samue, Owusu, Prince ve Gyamera, 2015; Siyez, 
2009; Tunç, Y1ldız ve Doğan, 2015). Bu sonuçlar doğrultusunda lise öğretmenlerinin disiplin sorunları karşısında yüksek öğretmen kontrolüne dayalı, geleneksel stratejileri uygulamaya devam ettikleri söylenebilir.

Eğitimde ve disiplinde amaç bireyin davranışında olumlu yönde değişim meydana getirmektir. Bu amaca, öğrencilerin uygun olmayan davranışlarını tekrarlanmasını önlerken, aynı zamanda iç kontrol mekanizmalarını geliştirerek ulaşılabilir. Ceza verme ve uyarma yöntemleri ise diş denetleme araçlarıdır. Her iki yöntem de yanlışın neden yanlış, doğrunun neden doğru olduğunu öğretmede, doğru olan davranışı başlatmada ve iç kontrol becerilerini geliştirmede tek başına yetersizdir (Smith ve Laslett, 2002). Ergenlik çağının temel özellikleri duygusal coşku ve taşkınlık, çabuk kurulan ve bozulan ilişkiler, kolay etkilenme, toplum içinde sivrilme ve ilgi çekmedir (Yavuzer, 2013). Özellikle orta ergenlik döneminde olan 15-17 yaş grubundaki öğrencilerin bağımsızlık dürtülerinin güçlendiği ve otonomi ihtiyaçlarının da arttığı göz önüne alındığında sık sık cezaya başvurma ve uyarma ergenlerin çevrelerindeki yetişkinlerle (okulda öğretmen evde ebeveynler) çatışmaya girmelerine neden olması açısından doğru bir yaklaşım değildir (Ocakçı, 2015). Bu açıdan bu stratejilerin pedagojik açıdan uygun olmadığı, öğrencilerde olumsuz duygu ve davranışlar oluşmasına zemin hazırladığı söylenebilir. Katılımcı öğretmenlerinde"ne yaparsan yap dinlemiyorlar, insanı çileden çıkarıyorlar bizim zamanımızda böyle değildi, bizim öğretmenlerimiz böyle yapmazdık, karşılarında ses bile çıkaramazdık" vb. ifadeler kullanmaları bu görüşü doğrular niteliktedir.

Buna rağmen öğretmenlerin öğrencilere ceza vermeye ve uyarmaya devam etmelerinin nedeni bir an önce sınıfta kontrolü ele alma ihtiyaçları olabilir. Çünkü sınıfı olumsuz etkileyen davranışlar olurken dikkatler dağılır ve öğretmen için öğretimi devam ettirmek zorlaşır (Jenkins ve Ueno, 2017; Sueb, 2013). Ceza, uzun dönemde etkili olmasa da uygulaması kolaydır, etkisini hemen o anda gösterir ve davranışı durdurur. Dolayısıyla öğretmenler ceza vererek hem öğrenciyi durdurmaya, hem de diğer öğrencilerin bu davranışta bulunmasını kısa bir sürede olsa önlemeye çalışıyor olabilirler. Ancak davranış̧̧ kurama göre ceza verme dikkati olumsuz davranışa çekmekte, sık yapılan uyarılar ise olumsuz davranışın pekişmesine neden olabilmektedir. Uygun davranışın ortaya çıkması, sürekliliğinin sağlanması ve güçlendirilmesi için olumlu davranışın pekiştirilmesi gerekmektedir (Charles, 2005). Uygun davranışa odaklanma ve pekiştirme, diğer öğrencile- 
rin de pekiştireç alan öğrencinin davranışını model alarak öğrenmesi açısından da önemlidir (Tekin İftar, 2014).Atılgan disipline göre de ödül vermek, etkili öğretmenleri daha az etkili olan öğretmenlerden ayıran temel özelliklerden biridir (Canter ve Canter, 2013). Bu araştırmada ise sadece dört öğretmen not yükseltme ve +/- verme gibi sembolik işaretlerle yapılan sınırlı ödüllendirmelere değinmiştir. Bu durumda ödül-cezaya diğer bir ifadeyle öğretmen kontrolüne dayalı disiplin modellerinin de sistematik bir şekilde uygulanmadığı, olumlu pekiştireçlerin ihmal edildiği, öğretmenlerin ceza ve uyarılarının da durumsal ve duygusal olduğu söylenebilir.

Katılımcılara göre öğrenci ile iletişim kurma, farkındalık oluşturma ve öğrencilere karşı olumlu yaklaşım tarzı/tutum sergileme disiplin sağlamada kullanılan diğer yöntemlerdir. Bu yöntemler etkileşime dayalı disiplin modellerinin vurguladığı temel stratejilerdir. Dolayısıyla bu sonuç, öğretmenlerin her ne kadar cezalandırma ve uyarma yöntemlerine ağırlık verseler de öğrencilere insancıl yaklaşmaya ve onları işbirliğine davet etmeye çalışmaları açısından olumlu bir sonuç olarak değerlendirilebilir. Bununla birlikte öğretmenlere kıyasla az sayıda öğrenci bu yöntemlerin kullanıldığıyla ilgili görüş belirtmiştir. Bunun nedeni öğrencilerin daha sık karşılaştıkları azarlamalar/bağırmalar, not kırmalar, dersi durdurma ve uyarılar arasında bu olumlu yaklaşımları fark etmemeleri olabileceği gibi öğretmenlerin uygulamada bu yöntemlere düşündüklerinden daha az yer vermeleri de olabilir. Araştırmadan elde edilen sonuçlar bu yöntemlerin uygulanış şekliyle ilgili öğretmen ve öğrenci görüşleri arasında farklılıklar olduğunu da göstermiştir. Örneğin öğretmenler öğrencilerle sınıf dışında bire-bir konuştuklarını, empatik dinleme yaptıklarını, davranışın sonuçlarını açıklayıp, nedenlerini araştırdıkların ifade ederken öğrenciler; öğretmenlerin onlarla herkesin içinde de konuştuklarını ve daha çok ögüt verdiklerini belirtmişlerdir. Öğretmenler öğrencilerde farkındalık oluşturmak için bir amaç belirlemelerine yardım ettiklerini, dersin önemine dikkat çektiklerini ve hayattaki başarı hikâyelerinden söz ettiklerini ifade ederken, öğrenciler öğretmenlerin kendi başarılarından ve hayat hikâyelerinden bahsettiklerini dile getirmişlerdir. Öğretmenler öğrencilere olumlu yaklaştıklarını, onlara saygı duyduklarını ve değer verdiklerini hissettirmeye çalıştıklarını ifade ederken öğrencilerin çoğunluğunun bu duyguları hissetmekten bahsetmediği saptanmıştır.

Davranış yönetiminde öğrencilere sorumluluğun öğretilmesi en önemli şeydir. Çünkü sorumluluğu öğrenme, öğrencilere kendilerini kontrol etmeyi 
de öğretir (Jones ve Jones, 2007). Ancak bunu yaparken ergenlerin özerkliğine müdahale etmek, kişiliğine zarar verecek değerlendirmeler yapmak, sürekli nasihat etmek veya konuyu gereğinden fazla uzatmak, ergeni başkalarının önünde eleştirmek ve davranışlarını başkalarıyla karşılaştırmak sağlıklı bir yaklaşım değildir (Yavuzer, 2013). Öğrenciler öğretmen-öğrenci ilişkisi iyi olduğunda daha iyi öğrenebilir, aksi takdirde en etkili öğretim tekniklerini uygulamanın bile faydası olmayabilir (Gordon, 2019). Bunun için gerek öğretmenlerin gerekse öğrencilerin açık ve dürüst olması, önemsendiklerini ve değer verildiklerini hissetmesi, birbirlerine gereksinim duymaları ve kurulan iletişimin her iki tarafın gereksinimlerini karşılaması gerekmektedir. Ayrıca bireylerin ahlâki konulara en hassas oldukları dönem, gelişim dönemleri açısından ergenlik dönemi olup, bu dönemin en belirgin davranış özelliği "kendi kendini yönetme" dir. Değerlerin doğrudan, teorik bir yaklaşımla ve baskıcı bir şekilde aşılanmaya çalışılması hem akademik hem de psikolojik olarak işlevsel değildir. Bunun yerine ergenlerin fikirlerindeki, davranışlarındaki tutarsızlıkları görebilmeleri için davranışlarıyla doğru biçimde yüzleşmelerini sağlamak, seçimlerinin olası bütün sonuçlarını inceleyerek, kendi davranışlarını geliştirme ve değiştirme sorumluluğunu almalarına yardım etmek gereklidir. Öğrencilerle doğru şekilde iletişim kurabilmek, deneyimlerden öğrenme ve kapasite geliştirme gibi içsel mekanizmalarını harekete geçirme açısından önemlidir. Böyle bir işbirliği ile ergenlerde değerlere ilişkin temel bilişsel sürecin yeniden yapılanmasına imkânı sağlanabilir (Koç, 2004). Bu durumda öğretmenlerin her ne kadar öğrencilerle iletişim kurmaya çalışsalar da geleneksel disiplin anlayışından sıyrılamadıkları, belirli bir davranışın doğruluğundan hareketle öğrenciye/öğrencilere o davranışı benimsetmeye çalıştıkları (öğrencilere kendilerinden bahsederek, öğüt vererek, davranışlarını eleştirerek vb.) söylenebilir. Dolayısıyla iletişim kurma, farkındalık oluşturma ve öğrencilere karşı olumlu yaklaşım tarzı/tutum sergileme yöntemleriyle ilgili öğretmen ve öğrenci görüşleri arasında gözlenen farklılıklar, kurulan iletişimin her iki tarafında ihtiyaçlarını karşılamamasından kaynaklanmış olabilir. Öğretmenlerin disiplin sağlama sürecinde öğrencilerle iletişim kuramadıklarından ve onlara ulaşamadıklarından yakınmaları, motivasyonsuzluk, tükenmişlik, hayal kırıklığı ve yetersizlik gibi olumsuz duygular yaşadıklarından bahsetmeleri; öğrencilerin de kendilerini öğretmenle iletişime kapadıklarını, davranışı yapmaya devam ettiklerini ve olumsuz duygular (öfke, kızgınlık) 
hissettiklerini belirtmeleri bu yorumu destekler niteliktedir. İlgili literatürde de öğretmenlerin sergiledikleri tutumlar ile öğrencilerin kızgınlık ve kin duyguları, motivasyonları, ilgileri ve derse katılımları arasında (BroeckelmanPost, Tacconelli, Guzmán, Rios, Calero ve Latif, 2016; Dedeoğlu, 2010; Habash, 2010; Sezer, 2018; Sürücü ve Ünal, 2018; Yücesoy, 2017), disiplin anlayışları ve kullandıkları disiplin modelleri ile mesleki tutumları ve tükenmişlik düzeyleri arasında ilişki olduğunu saptayan birçok araştırma bulunmaktadır (Cemaloğlu ve Kayabaşı, 2007; Durak ve Seferoğlu, 2017; Polat, Arslan ve Satıcı, 2016; Tümkaya, 2005).

Bununla birlikte "öğrenciyle bire-bir iletişime" geçme gerek öğretmenler gerekse öğrenciler tarafından disiplini sağlama açısından en etkili yöntem olarak belirtilmiş, bunu empatik dinleme, öğretmen ve öğrencilerin birlikte vakit geçirmesi izlemiştir. İlgili literatürde bu yöntemlerin diğer eğitim kademelerinde de öğretmen ve öğrenciler tarafından en etkili yöntemler olarak değerlendirildiği araştırmalara rastlanmaktadır (Aküzüm ve Nazlı, 2017; Gündüz ve Konuk, 2016; Konti, 2011; Kyriacou ve Martin, 2010; Yllmaz ve Babaoğlan, 2013). Öğretmen-öğrenci iletişimi sadece eğitimin niteliğini arttırma açısından değil, öğrencilerin psikolojik ve sosyal yönden gelişimini de etkilemesi açısından eğitim sisteminin temelini oluşturmaktadır (Yılmaz ve Babaoğlan, 2013). Dolayısıyla bu sonuç aralarında çatışmalar olmakla birlikte teneffüste birlikte yürüme, konuşma, selamlaşma vb. çok sınırlı zamanlar olsa da öğrencilerin öğretmenlerinin ders dışında onlarla ilgilenmesine gereksinim duyduklarını, öğretmenlerin de ergenlerin "empati, fark edilme, anlaşılma, önemsenme, kabul edilme, değerli hissetme vb." temel ihtiyaçlarının farkında olduklarını gösterme açısından önemlidir.

Araştırmadan elde edilen bulgulara göre öğretmenler kendilerini öğrenciler de öğretmenlerini; kabalık, derse karşı ilgisizlik, ders akışını engelleme ve sorumlulukların yerine getirmemeyle ilgili disiplin sorunların yönetmede daha yeterli algılamaktadır. Katılımcıların açıklamalarına göre kabalık karşısında öğrenciyle konuşma/açılama yapma; derse karşı ilgisiz davranışlar karşısında uyarma, beden diliyle davranıştan hoşlanmadığını gösterme, not kıracağını söyleme ve konuşma; ders akışını engelleme ve sorumluluklarını yerine getirmeme davranışları karşısında da uyarma, +/not vereceğini söyleme, yok yazacağını söyleme; ortam ve eşyalara zarar verme davranışları karşısında da tutanak tutacağını söyleme, disipline gönderme/göndereceğini söyleme yöntemleri kullanılmaktadır. Bu davranışlar 
liselerde en sık karşılaşılan disiplin sorunları arasındadır (Akar, 2006; Akpınar ve Özdaş, 2013; Aydın, 2011; Gümüş, 2013; Siyez, 2009; Tunç, Yıldız ve Doğan 2015; Yücesoy, 2017). Bu çalışmada da katılımcıların öğretmen müdahalesinden bir süre sonra davranışın tekrarlandığını ve sınıf geneline yayıldığın belirtmeleri ve disiplin sorunlarına kalıcı çözümler konusunda öğretmenlerde değişim/gelişimi vurgulamaları öğretmen müdahalesini uzun vadede yeterli bulmadıklarını, öğretmenlerin o an "davranışı durdurması" nı yeterlik olarak algıladıklarını düşündürmektedir.

Katılımcılar etkili disiplin için yapılması gerekenleri çoğunlukla öğretmen, okul ortamı, yasa ve yönetmelikler açısından vurgulamış, öğrenci, veli ve medya ile ilgili görüşler bazı öğretmen ve öğrenciler tarafından dile getirilmiştir. Bu sonuç sorunun öncelikle kendi koşulları içinde değerlendirilmesi, aynı zamanda çok boyutlu ele alınabilmesi açısından olumlu değerlendirilebilir. Öğretmen teması altında öğretmenlerin çoğunluğu etkili disiplin için paydaşlarla işbirliğini vurgulamıştır. Öğrenciler ise çoğunlukla öğretmenlerin sorun davranışı inceleme, nedenleri araştırma, bunu yaparken öğrenciyle doğru biçimde iletişim kurma, önyargılardan sıyrılma, öğrencilerin değişebileceğine inanma ve farkındalık geliştirme gibi sosyal beceriler ve öğrencilere yönelik olumlu tutum ve inançlar üzerinde durmuşlardır. Okul ortamıla ilgili olarak öğretmenler çoğunlukla sosyal alanların arttırılması, öğretmenlerin öğrencilerle birlikte sohbet edebileceği sohbet odaları oluşturulması, fiziki koşulların iyileştirilmesi üzerinde durmuş, öğrenciler haftalık ders çizelgelerinin derslerin zorluğuna dikkat edilerek hazırlanması, fiziki koşulların iyileştirilmesi ve kuralların kararlılıkla uygulanmasını dile getirmişlerdir. Eğitimle ilgili yasa ve yönetmeliklerde bir düzenlemeye gidilmesi çoğunlukla öğretmenler tarafından dile getirilmiş, öğretmenler bu temada eğitim programlarının işlevselliğini artırma, karnelerde akademik başarının yanında sosyal becerilere de yer verme, öğretmenlik mesleğine gereken önemi verme, disiplin yönetmeliğini gözden geçirme vb. konusunda açıklamalar yapmışlardır. Öğrencilerin görüşleri ise programların işlevselliği, teknolojinin daha etkin kullanılması ve programdaki ders sayısının azaltılması yönündedir. Ailelerin ve öğrencilerin gelişimini sağlama (seminer, konferans vb.) gerekliliği ve medya desteği birkaç öğretmen tarafından vurgulanmış, öğrenciler de ergenlik ve insan ilişkileri konusunda eğitim ihtiyaçlarını dile getirerek, okulda onlara da aktif görevler verilmesi gerektiğini dile getirmişlerdir. 
Katılımcıların tamamının öğretmen davranışlarıyla ilgili görüş belirtmeleri en çok zaman geçirdikleri okul ortamında sosyal çevrelerinin öğretmenöğrencilerden oluşması açısından doğaldır. Öğretmen ve öğrenci görüşleri arasındaki farklılıklar ise tarafların farklı ihtiyaçlar ve beklentiler içinde olmalarından kaynaklanmış olabilir. Ergenin bir yetişkin olma çabası; fiziğiyle, aklıyla, kişiliğiyle bir "var olma mücadelesi" ni, yaşama bakış açısı ve hayat felsefesiyle biçimlendirdiği "saygınlık kazanma" eylemlerini içermektedir. Bu nedenle ergenler duygularında, düşünce ve davranışlarında fark edilme, kabul edilme, takdir edilme ihtiyaçlarını en yoğun yaşayan kişilerdir (Güçlü Yılmaz, 2015; s.36). Dolayısıyla öğrencilerin öğretmenlerle ilgili dile getirdikleri ve literatüre benzer olan sonuçlar (Cangelosi, 2016; Duran, 2011; Pehlivan ve Demirtaş, 2019; Saenz, 2011) daha insancl yaklaşımlara ve rehberliğe ihtiyaç duydukları, şeklinde yorumlanabileceği gibi, okuldaki öğretmenöğrenci iletişimindeki eksikliklerin bir göstergesi olarak da kabul edilebilir. Öğretmenlerin etkili disiplinde paydaş işbirliğini vurgulaması ise disiplin konusunda daha çok desteğe ihtiyaç duymalarından veya okul psikolojik danışmanından ve okul yönetiminden gerekli yardımı alamamalarından kaynaklanmış olabilir. İlgili literatürde rehberlik servisinin görev ve sorumluluklarını gerçekleştirmede sıkıntılar yaşadığını, okul psikolojik danışmanlarının öğretmenlerden işbirliği, okul yönetiminden destek beklediğini, okulda yapılan rehberlik hizmetlerinin öğretmenler ve öğrenciler tarafından yeterli bulunmadığını, özellikle lise düzeyinde ailelerle iletişimde sorunlar yaşandığını gösteren araştırmalar olması bu yorumu destekler niteliktedir (Akar, 2006; Akpınar ve Bengisoy, 2017; Ceylan ve Akar, 2010; Korkut-Owen ve Owen, 2008; Sadık ve İnal, 2011; Tunç, İnandı, Öksüz ve Çal, 2013; Tuzgöl Dost ve Keklik, 2012). Eğitimle ilgili yasa ve yönetmeliklerle ilgili öğretmenlerin öğrencilere kıyasla çok farklı özelliklere değinmesi mevzuata hâkim ve süreci gözlemleyen grup olmalarından dolay1 beklenen bir sonuç olmuştur. Bununla birlikte her iki tarafında programların işlevselliği ve teknolojinin daha etkili kullanımını dile getirmeleri, hayata yakın olmayan derslerin davranıslar üzerindeki olumsuz etkilerini bire-bir yaşamalarından kaynaklanmış olabilir. Lise öğrencilerinin en önemli problem alanının okul hayatında başarısızlık/akademik gelişmeyle ilgili olduğunu gösteren araştırma sonuçları bu görüşü destekler niteliktedir (Güçlü Yılmaz, 2015; Gümüş, 2013; Tunç, Yıldız ve Doğan, 2015). Okulda geçirilen zamanın kalitesi; öğretmenin, programın, sosyal aktivitelerin, reh- 
berlik servisinin, öğrenme ortamının vb. tüm okul ortamının kalitesiyle doğru orantılıdır. Kaliteli öğrenme ortamları, öğrencilerin okul memnuniyetinin yanı sıra akademik başarısını, öğrenmeye katılımını ve genel yaşam kalitesini geliştirir (Ames, 1992). Dolayısıyla katılımcıların okul ortamıla ilgili dile getirdikleri özelliklerin de gerek öğrenciler gerekse öğretmenler için okulda geçirilen zamanın ve eğitimin kalitesini arttırmaya yönelik düzenlemeler olduğu görülmektedir.

Özetle bu araştırmada liselerde disiplinin uygulamalarının davranışı kontrol etmeye dayalı olduğu (1), ödül-cezaya dayalı yaklaşımların sistematik uygulanmadığı (2), öğretmen-öğrenci etkileşimine dayalı stratejilerin öğrencide farkındalık oluşturma ve sorumluluk almayı öğretmekten çok, nasihat etme ve akıl verme ile sınırlı kaldığı (3), disiplin uygulamalarıyla ilgili öğretmen ve öğrenci görüşlerinde benzerliklerin yanı sıra önemli farklılıkların olduğu (4), disiplin sağlamaya yönelik yeterlik algısının daha çok "davranışı durdurma" (5), etkili disiplin sağlamaya yönelik görüşlerin ise disiplin sorunlarını yaratan koşulların iyileştirilmesine yönelik olduğu saptanmıştır (5). Bu araştırmadan elde edilen sonuçlar sınırlılıkları çerçevesinde değerlendirilmelidir. Araştırma bir meslek lisesindeki öğretmen ve öğrencilerin görüşleri alınarak gerçekleştirilmiş, diğer lise türlerinden katılımcı olmamıştır. Farklı lise türlerinden öğretmen ve öğrenci görüşleri alınarak liselerdeki disiplin uygulamaları hakkında görüşler karşılaştırılabilir. Araştırmada katılımcıların görüşleri alınmış, ancak sınıf ortamındaki uygulamalar incelenmemiştir. Görüşmenin yanı sıra sınıf gözlemleri de yapılarak süreç hakkında daha derinlemesine bilgiler elde edilebilir. Disiplin çok boyutlu bir kavram olup bu araştırmada öğretmen ve öğrenci algısına odaklanılmıştır. Benzer çalışmalarda örnekleme yöneticiler, okul psikolojik danışmanları ve veliler eklenerek, karşılıklı beklentiler, yaşanan sorunlar, birlikte yapılması gerekenler üzerine bir değerlendirme yapılabilir. 


\section{EXTENDED ABSTRACT}

\section{The Views of Teachers and Students on Disciplinary Practices in High Schools \\ *}

Fatma Sadık - Onur Yalçın

Çukurova University-MONE

The social structure of the class is as highly important as the appropriateness and quality of teaching activities in the classroom in achieving the objectives of education because a regular and safe environment and healthy communication are required for effective learning, which is achieved by discipline. To this end, it is attempted to provide children with a safe environment where they can develop healthily by setting the limits they need in the school and classroom environment. In addition to the indicators of teacher performance such as being quiet, being tidy, and fulfilling the requirements of learning, they also have dimensions that concern school management such as school security, timing, and the functioning of the process within the framework of plans (Raby, 2012).

Since the social order requires intervention to behaviors, how teachers deal with/manage problem behaviors becomes extremely important because the purpose of discipline is to ensure that children distinguish between the right and the wrong and between the good and the bad and gain self-control/self-regulatory skills (Yavuzer, 2013). Therefore, the fact that teachers deal with problem behaviors properly in social, legal, and pedagogical terms has a very significant effect not only in terms of preventing recurrence but also teaching students how to behave correctly (Wehby, Tally and Falk, 2004). Teachers should behave in a way that students can model, should help students to understand their own and others' emotions and to control their desires, and should give students responsibility and control of their own behaviors, which is of much greater importance, especially in high schools, because adolescence is the most critical period in terms of both gaining values and adolescents' adaptation to the changing society (Koç, 2004). Accordingly, studies on how to achieve discipline at the high school level were reviewed. However, it was observed that the studies focused on adolescent crimes committed 
throughout the school, reasons for disciplinary action, disciplinary punishments imposed, administrative regulations, and peer bullying. It was determined that the number of studies on the perception of discipline and how discipline is achieved was limited. Based on these reasons, it was needed to conduct a study examining disciplinary practices in high schools from the perspectives of teachers and students.

\section{Method}

Research Design: This study, which aimed to examinethe views of teachers and studentson disciplinary practices in high schools in depth, was designed in a phenomenological approach, which is one of the qualitative research designs.

Participants: The study was conducted with teachers and students in a vocational high school in the city center of Adana. While typical case sampling was used to determine the school, maximum diversity sampling was used to determine teachers, and the criterion sampling method was used to determine students. This study was conducted with 18 teachers and 16 students.

Data Collection Tools: In the study, interview forms developed by the researchers in accordance with the relevant literature and expert opinions were used to collect the data. The study data were collected in the spring semester of the 2014-2015 academic year, and the interviews were conducted using a voice recorder with the permission of the participants.

Data Analysis: The data obtained in the study were analyzed by the content analysis technique. At the first stage, the voice recordings were transcribed in the Word environment, then the raw data texts were encoded independently by the researchers, and the inter-coder reliability for each question was separately calculated using the formula of Miles and Huberman (1994, p.64). 
Results, Discussion, and Recommendations: As a result of the study, it was observed that the majority of the participants agreed that the punishment and warning methods were applied for disciplinary problems, and scolding/shouting, lowering the performance grade and ceasing the course were the most common punishments. In accordance with these results, it can be said that high school teachers continue to apply traditional strategies based on high teacher control in the face of disciplinary problems. According to the participants, communication with the student, awareness-raising and exhibiting a positive approach/attitude towards students were other methods used to achieve discipline. A small number of students expressed their views on the use of these methods compared to teachers, the reason for which may be that students did not notice these positive attitudes among scolding/shouting, taking points off, ceasing the course and warnings that were more frequently encountered by students, and also, teachers used these methods less in practice than they thought. Nevertheless, "one-to-one communication with students" was stated as the most effective method in terms of achieving discipline by both teachers and students. Teacher-student communication constitutes the basis of the education system not only in terms of increasing the quality of education but also in terms of affecting the psychological and social development of students. Therefore, this result is important in terms of showing that students need their teachers to take care of them outside of the classroom although there are conflicts between them and that teachers are aware of the basic needs of teenagers such as "empathy, being noticed, being understood, being cared for, acceptance, and feeling valuable."

According to the results obtained from the study, teachers perceived themselves to be more competent in managing disciplinary problems related to rudeness, indifference to the course, disrupting the flow of the course and failure to fulfill responsibilities, and students also perceived their teachers to be more competent in them. Nevertheless, the fact that the participants stated that the behavior was repeated and spread throughout the classroom some time after teacher intervention suggested that they did not find teacher intervention sufficient in the long term and that teacher perceived "ceasing the behavior" as a competence at that moment. According to the teachers, the most important problems experienced in the disciplinary process were students' refusal to accept their 
own mistakes, closing themselves to communication, repeating the behavior after a while, and the occurrence of negative emotions. The participants mostly emphasized the things to do for effective discipline in terms of teachers, school environment, laws and regulations.

\section{Kaynakça / References}

Ada, S. ve Ölçüm Çetin, M. (2006). Eğitim ve öğretim ortammda disiplin nedir?. Ankara:Nobel Yayinclik.

Ağrın, E. (2019). Bir ortaöğretim okulundaki disiplin uygulamalarnnn eleştirel bir çözümlemesi. (Yayımlanmamış doktora tezi). Ankara Üniversitesi, Ankara.

Akar, N. (2006). Ortaöğretim kurumlarnnda karşlaş̧lan disiplin sorunlarn ve eğitim yöneticilerinin çözüm yaklaşımları. (Yayımlanmamış yüksek lisans tezi). Pamukkale Üniversitesi, Denizli.

Akpınar, B. ve Bengisoy, A. (2017). Rehber öğretmenlerin okul müdürlerinin rehberlik hizmetlerine ilişkin görüşleri. Current Research in Education, 3(3) , 129-141.

Akpınar, B. veÖzdaş, F. (2013). Lise disiplin sorunlarının cinsiyet değişkeni açısından incelenmesi. Dicle Üniversitesi Ziya Gökalp Eğitim Fakültesi Dergisi, 21, 20-29.

Aküzüm, C. veNazl, K. (2017). Sınıf öğretmenlerinin sınıf yönetiminde karşılaştıkları disiplin sorunları, nedenleri ve bu sorunlarla baş etme yöntemlerinin değerlendirilmesi. International e-Journal of Educational Studies,1(2), 88-102.

Aktaş, A. (2019). Sinff yönetiminde sinıf içi disiplin sorunlan ve çözüm yöntemleri konusunda yönetici ve öğretmen görüşleri. (Yayımlanmamış yüksek lisans tezi). Maltepe Üniversitesi, İstanbul.

Ames, C. (1992). Classrooms: Goals, structures and student motivation. Journal of Educational Psychology,84(3), 261-271.

Andegiorgis, G. E. (2020). Counselling approaches used in solving students' disciplinary problems in secondary schools in Keren sub-zone, Ansebaregion, Eritrea. Global Journal of Psychology Research: New Trends and Issues, 10(1), 95-101.

Arak, H. ve Arslan, N.Ö. (2008). Jacobs Kounin'e göre sinıf yönetimi teknikleri. Sosyal Bilimler Enstitüsü Dergisi, 25, 193-207.

Arens, A. K., A. J. S. Morin, R. and Watermann, R. (2015). Relations between classroom disciplinary problems and student motivation: Achievement as a potential mediator? Learning and Instruction, 39, 184-193.

Atıc1, M. ve Çekici, F. (2009). Ortaöğretimdeki öğretmen ve öğrencilerin istenmeyen davranışlarla baş etme konusundaki görüşlerinin karşılaştırılması. Educational Administration: Theory and Practice, 15(60), 495-522. 
Aydın, B. (2006). Öğretmenlerin kendi sınıf disiplin sistemlerini oluşturması. Sosyal Bilimler Araştırmaları Dergisi, 1(2), 19-32.

Aydın, B. (2011). Rehber öğretmenlerin istenmeyen öğrenci davranışlarına ilişkin çözüm önerileri. e-Journal of New World Sciences Academy Education Sciences,6(4), 2469-2481.

Bilir, A., Kuru, S. ve Tezcan, F. (2007). Muğla ili ortaöğretim okullarında disiplin uygulamalarına ilişkin yönetici ve öğretmen görüşleri. Muğla Üniversitesi Sosyal Bilimler Enstitüsü Dergisi, 19, 58-72.

Broeckelman-Post, M. A., Tacconelli, A., Guzmán, J., Rios, M., Calero, B. and Latif, F. (2016). Teacher misbehavior and its effects on student interest and engagement. Communication Education,65(2), 204-212.

Burden, P.R. (1995). Classroom management and discipline: methods to facilitate cooperation and instruction. Longman Publishers USA, 10 Bank Street, White Plains, NY 10606-1951.

Cangelosi, J. S. (2016). Sinıf yönetimi stratejileri: Öğrencilerin işbirliği yapmaların să̆lama ve bu işbirliğini devam ettirme. (Çev. R. Hoş, M.Toprak) (7. Basımdan çeviri). Ankara: Nobel Akademik Yayıncllk.Çeviri tarihi 2016.

Canter, L. ve Canter, M. (2013). Assertive Discipline. Manning, M. L. And Bucher, K. T. (Ed.) (2013). Classroom Management: Models, Applications, and Cases (içinde). Pearson: Boston, Massachusetts.

Cemaloğlu, N. ve Kayabaşi, Y. (2007). Öğretmenlerin tükenmişlik düzeyi ile sinff yönetiminde kullandıkları disiplin modelleri arasındaki ilişki. Gazi Üniversitesi Gazi Eğitim Fakültesi Dergisi, 27(2), 123-155.

Ceylan, M. ve Akar, B. (2010). Ortaöğretimde okul-aile işbirliği ile ilgili öğretmen ve veli görüşlerinin incelenmesi. Çankır Karatekin Üniversitesi Sosyal Bilimler Enstitüsü Dergisi,2, 43-64.

Charles, C. M. (2005). Building classroom discipline. San Diego State University.

Creswell, J. W. (2012). Educational research: planning, conducting and evaluating quantitative and qualitative research (4. Baskı). Pearson Education Inc.

Cropley, A. (2002). Qualitive research methods: An introduction for students of psychology and education. University of Latvia. Zinatne.

Çankaya, İ. ve Çanakçı, H. (2011). Sınıf öğretmenlerinin karşılaştıkları istenmeyen öğrenci davranışları ve bu davranışlarla başa çıkma yolları. Turkish Studies, 6(2), 307-316.

Çelikkaleli, Ö. (2010). Ergenlerin yetkinlik inançları ile depresyon, benlik saygısı, iç-dış kontrol odă̆̆, sürekli öfke ve öfke ifade biçimleri arasindaki ilişkinin incelenmesi. (Yayımlanmamış yüksek lisans tezi). Mersin Üniversitesi, Mersin. 
Çerçi, H.Y. (2009). Devlet okullarında görevli öğretmenlerin disiplin yaklaşımları. (Yayımlanmamış Yüksek Lisans Tezi). Maltepe Üniversitesi, İstanbul.

Çetin, B. (2013). Sınıfta istenmeyen öğrenci davranışlarıyla ilgili sınıf öğretmenlerinin karşılaştıkları sorunlar ve çözüm önerileri. Ahi Evran Üniversitesi Kırşehir Eğitim Fakültesi Dergisi, 14(1), 255-269.

Dedeoğlu, Ö. (2010). Meslek lisesi öğrencilerinin disipline aykır davranışta bulunmalarnda ailenin etkisi. (Yayımlanmamış yüksek lisans tezi). Marmara Üniversitesi, İstanbul.

Demir, F. (2013). Ortaokullarda öğrencilerin disiplinsiz davranışlar ve bu davranışlarm sebepleri (Batman ili merkez ilçesi örneği). (Yayımlanmamış yüksek lisans tezi). İnönü Üniversitesi, Malatya.

Durak, H. Y. ve Seferoğlu, S. S. (2017). Öğretmenlerde tükenmişlik duygusunun çeşitli değişkenler açısından incelenmesi. Gazi Üniversitesi Gazi Eğitim Fakültesi Dergisi, 37(2), 759-788.

Duran, C. (2011). Ortaögretim okullarında okul yönetimine yansıyan disiplin sorunlar ve okul yöneticilerinin çözüm yaklaşımları. (Yayımlanmamış yüksek lisans tezi). Uş̧ak Üniversitesi, Uş̧ak.

Edwards, C. H. (2004). Classroom discipline and management, Newyork: John Wiley and Sons Publishes.

Edwards, C. H. (2012). Classroom discipline and management. McMillan.

Erzurum, H. ve Kır, İ. (2011). İlköğretim öğretmenlerinin kullandıkları disiplin türleri/types of discipline that primary school teachers practice. Mustafa Kemal Üniversitesi Sosyal Bilimler Enstitüsü Dergisi, 8(16), 271-285.

Evertson, C. M. ve Emmer, E. T. (2012). Classroom management for elemantary school teachers (9.th . Ed.), (Çev. Ed. A. Aypay). Ankara: Nobel Akademik Yayıncilik.

Glesne, C. (2013). Nitel araştırmaya giriş (Çeviri Editörleri: Ali Ersoy ve Pelin Yalçınoğlu). (2. Baskı). Anı Yayınclık.Çeviri tarihi. 2011

Gordon T. (2019). Etkili ö̆retmenlik eğitimi (10. Baskı, Çev. S. Karakale). Profil Kitap.

Gökçen, E. (2018). Sinıfiçi disiplini bozan davranışlara yönelik öğretmen görüşleri (Şanlıurfa ili örneği.). (Yayımlanmamış yüksek lisans tezi). Muğla Sıtkı Koçman Üniversitesi, Muğla.

Gökyer, N. ve Doğan, B. (2016). İstenmeyen öğrenci davranışları ve nedenlerine ilişkin yönetici ve öğretmen görüşleri. Firat University Journal of Social Sciences/Sosyal Bilimler Dergisi,26(1), 93-105. 
Güçlü Yılmaz, F. (2015). Ergen suçları ergen suçlulara yönelik okul içindeki düzenlemeler ve Türk Ceza Kanunu karşılaştırması. Ankara Barosu Dergisi, 3, 334354.

Güder, S. Y., Alabay, E. ve Güner, E. (2018). Okul öncesi öğretmenlerinin sınıflarında karşılaştıkları davranış problemleri ve kullandıkları stratejiler. Elementary Education Online, 17(1), 414-430.

Gümüş, A. (2013). Liselerde disiplin cezasına konu olan davranışlarm değerler perspektifinden incelenmesi (Üsküdar örneğil 1980-2010). (Yayımlanmamış yüksek lisans tezi). Marmara Üniversitesi, İstanbul.

Gündüz, H. B. ve Konuk, S. (2016). İlkokul öğretmenlerin karşılaştıları istenmeyen davranışlar ile baş etme stratejileri. Yuldız Journal of Educational Research,1(1), 37-54.

Habash, S. H. (2010). Exploring the relationship between perceived teacher nonverbal immediacy and perceived teacher misbehaviors on student course retention in urban community colleges. University of California, Irvine and California State University, Long Beach.

Hanhan, A. (2012). Onarnc disiplin modelinin liselerde akran istismarı ve şiddet üzerindeki etkilerinin incelenmesi. (Yayımlanmamış doktora tezi). Dokuz Eylül Üniversitesi, İzmir.

Hönicke, N. (2003). Jacob S. Kounin'e göre sınıf yönetimi teknikleri. (Çevirenler: Arak, H. ve Arslan, N.Ö.). Sosyal Bilimler Enstitüsü Dergisi, 25(2). 193 - 207.

Humphreys, T. (1998). Disiplin nedir? Ne değildir? [A different kind of discipline]. (B. Celik, Trans.). Epsilon Yayıncilik.

Infantino, J. and Little, E. (2005). Students' perceptions of classroom behaviour problems and the efectiveness of different disciplinary methods. Educational Psychology, 25(5), 491-508.

İnce, B. (2011). Sinıfta istenmeyen davranışlara karşı öğretmenlerin disiplin uygulamalarıla ilgili ilköğretim 5. sinfföğrencilerinin görüşlerinin incelenmesi (İstanbul ili örneği). (Yayımlanmamış yüksek lisans tezi). Marmara Üniversitesi, İstanbul.

Jenkins, A. and Ueno, A. (2017). Classroom disciplinary climate in secondary schools in England: What is therealpicture?.British Educational Research Journal, 43(1), 124-150. doi: 10.1002/berj.3255.

Jones, V. F. and Jones, L. S. (2007). Comprehensive classroom management, creating communities of support and solving problems ( $8^{\text {th }} \mathrm{Ed}$.). Allyn and Bacon Company.

Kaçar, T. (2018). Ortaöğretim kurumlarında karşılaşılan disiplin sorunları. Uluslararası Sosyal Araştırmalar Dergisi,11(58),524-534. 
Kahveci, N. G. (2012). Genel liselerde karşılaşılan disiplin sorunlarının uzamsal incelenmesi: İstanbul'dan Bir İlçe Örneği. Educational Policy Analysis and Strategic Research, 7(1), 64-92.

Koç, M. (2004). Gelişim psikolojisi açısından ergenlik dönemi ve genel özellikleri. Sosyal Bilimler Enstitüsü Dergisi, 17(2), 231-256.

Konti, F. (2011). Teachers and students perceptions towards teachers classroom management applications in primary schools. Procedia Social and Behavioral Sciences, 15, 4093-4097.

Korkut-Owen, F. and Owen, D. (2008). Okul psikolojik danışmanlarının rol ve işlevleri: yöneticiler ve psikolojik danışmanların görüşleri. Ankara Üniversitesi Ĕ̆itim Bilimleri Fakültesi, 41(1), 207-221.

Koutrouba, K. (2013). Student misbehaviour in secondary education: Greek teachers' views and attitudes. Educational Review, 65(1), 1-19.

Kök, M. (2007).Ortaöğretim kurumlarındaki öğretmen, rehber öğretmen ve yöneticilerinin ortaöğretim kurumları ödül ve disiplin yönetmeliğindeki ceza gerektiren davranışlar ile cezalara ilişkin görüşleri. (Yayınlanmamış doktora tezi). Hacettepe Üniversitesi, Ankara.

Kyriacou, C. and Ortega Martín, J. L. (2010). Beginning secondary school teachers' perceptions of pupil misbehaviour in Spain. Teacher development, 14(4), 415426.

Livumbaze, A. G. (2017). Impact of students' motivation and discipline on academic achievement in public secondary schools in Hamisi Sub-County, Kenya. European Journal of Education Studies, 3(1), 181-201.

Martin, G. and Pear, J. (2007). Behavior modification: What it is and how to do it (Eighthedition). Englewood Cliffs, NJ: Prentice-Hall, Inc.

Masekoameng, M. C. (2010). The impact of disciplinary problems on educator morale in secondary schools and implications for management. (Unpublished Doctoral dissertation). University of South Africa. Africa.

Maya, I. (2004). Mesleki-teknik liselerde istenmeyen öğrenci davranışlarına gösterilen öğretmen tepkileri. XIII. Ulusal Eğitim Bilimleri Kurultay1 6-9 Temmuz 2004, İnönü Üniversitesi Eğitim Fakültesi, Malatya.

Merriam, S. (2013). Qualitative research and case study applications in education. JosseyBass.

Miles, M. B. and Huberman, A. M. (1994). Qualitative data analysis. An expanded source book. Sage Publication. 
Ocak Karabay, Ş. ve Şahin Ası, D. (2019). Okul öncesi öğretmenleri sınıftaki farklı durumlarla nasıl başa çıkıyorlar? Öğretmen bildirimlerine dayalı bir çalışma. Uşak Üniversitesi Ĕ̈itim Araştırmaları Dergisi,5(1), 87-108.

Ocakçı, A. F. (2015). Ergenlik dönemi özellikleri. A. F. Ocakçı and F. Üstüner Top (Ed.), Yetişkinliğe bir adım kala ergen sağ̆lı̆̆ içinde (s.1-7). Göktuğ Basım ve Yayın Dağıtım.

Ombira, D. and Aluko, O. J. (2011-2012). Challenges Facing Teachers in Enhancing Discipline among Secondary School Students in Kuria West, Migori County. Abstracts of Post graduate Research Projects/ Thesis, Mount Kenya University.

Öngören Özdemir, S. ve Tepeli, K. (2016). Okul Öncesi Öğretmenlerinin Saldırgan Davranışlarla Baş Etme Stratejilerinin İncelenmesi. Ahi Evran Üniversitesi Kırşehir Eğitim Fakültesi Dergisi, 17(2), 51-70.

Öz, E. Z. (2012). Öğretmen, öğrencive ailelerin ilköğretim 2. kademede gözlenen disiplin problemleri ve baş etmede kullanulan stratejiler ile ilgili görüşlerinin incelenmesi. (Yüksek lisans tezi). Çukurova Üniversitesi, Adana.

Öztürk A. (2016). Okul yöneticilerinin bakış açısından ilköğretim kurumlarmda karşlaşılan disiplin sorunlarının incelenmesi.(Yayımlanmamıs yüksek lisans tezi). Gaziantep Üniversitesi, Gaziantep.

Öztürk, Y. ve Gangal, M. (2016). Okul öncesi eğitim öğretmenlerinin disiplin, sınıf yönetimi ve istenmeyen davranışlar hakkındaki inançları. Hacettepe Üniversitesi Eğitim Fakültesi Dergisi, 31(3), 593-608.

Pala, A. (2010). Sınıfta istenmeyen öğrenci davranışların önlemeye dönük disiplin modelleri. Manas Sosyal Bilimler Dergisi, 7(13),171 - 179.

Pehlivan, F. (2017). Ortaokul ve liselerde yaşanan disiplin problemlerinin bazı değişkenler açısından incelenmesi. (Yayımlanmamış doktora tezi). İnönü Üniversitesi, Malatya.

Pehlivan, F. ve Demirtaş, H. (2019). Ortaokul ve liselerde yaşanan disiplin problemlerinin çözümüne yönelik yönetsel uygulamalar. E-Uluslararası Eğitim Araştırmaları Dergisi, 10(2), 31-50.

PISA. (2011). PISA in focus 2011.12.10. 2020. https://www.oecd.org/pisa/49012097.pdf. tarihinde erişildi.

Polat, S., Arslan, Y. ve Satıc, A. (2016). Öğretmenlerin meslekî tutumları ile sınıf disiplin modeli tercihleri arasındaki ilişki. Gazi Üniversitesi Gazi Eğitim Fakültesi Dergisi,36(3), 675-691.

Raby, R. (2012). School rules. Obedience, discipline and elusive democracy. University of Toronto Pres. 
Saenz, M. (2011). Classroom management: An emphasis on positive discipline. (Unpublished doctoral dissertation). Fresno Pacific University, USA.

Sadık, F. ve İnal, U. (2011). Ortaöğretim kurumlarında karşılaşılan disiplin problemlerinin öğretmen görüşlerine göre değerlendirilmesi (Adana ili örneği). 20. Ulusal Eğitim Bilimleri Kurultayı, 1, 8-10 Eylül 2011, Burdur, Türkiye.

Salifu, I. and Agbenyega, J. S. (2012). Impact of disciplineissues on school effectiveness: The views of some Ghanaian Principals. MIE Journal of Educational Studies. Trends and Practic,2(1), 50-65.

Samue, A., Owusu, F., Prince, L. ve Gyamera, A. (2015). Managing school discipline: The students' and teachers' perception on disciplinary strategies. British Journal of Psychology Research, 3(2), 1-11.

Sarıtaş, M. (2006). Öğretmen adaylarının değerlendirmelerine göre sınıfta istenmeyen öğrenci davranışlarını değiştirmek ve düzeltmek amacıyla yararlanılan stratejiler. Uludă̆ Üniversitesi Ĕ̆itim Fakültesi Dergisi, 19(1), 167-187.

Sezer, Ş. (2018). The effects of teachers' classroom management attitudes on students' development: A phenomenological analysis. Hacettepe Üniversitesi Ĕ̈itim Fakültesi Dergisi,33(2), 534-549.

Smith, C. J. and Laslett, R. (2002). Effective classroom management. Taylor and Francis Group.

Siyez, D. M. (2009). Liselerde görev yapan öğretmenlerin istenmeyen öğrenci davranışlarına yönelik algılanı ve tepkileri. Pamukkale Üniversitesi Eğitim Fakültesi Dergisi, 1(25), 67-80.

Sueb, R. (2013). Pre-service teachers' classroom management in secondary school: managing for success in teaching and learning. Procedia-Social and Behavioral Sciences,90, 670-676.

Sürücü, A. ve Ünal, A. (2018). Öğrenci motivasyonunu artıran ve azaltan öğretmen davranışlarının incelenmesi. Uluslararası Toplum Araştırmalan Dergisi, 8(14), 255- 295. Doi: https://doi.org/10.26466/opus.404122

Tauber, R. T. (2007). Clasroom Management: Sound the oryand effective pratice.Greenwood Publishing Group, Westport.

Tekin İftar, E. (2014). Eğitim Psikolojisi. G. Can (Ed.), Klasik koşullanma ve edimsel koşullanma (s.165-186, 5. baskı). Anadolu Üniversitesi Yayını.

Temitayo, O., Nayaya, M. A. and Lukman, A. A. (2013). Management of disciplinary problems in secondary schools: Jalingo Metropolis in focus. Global Journal of Human Social Science, Linguistics and Education, 13(14), 7-19. 
Temiz, S. (2020). Okul öncesi öğretmenlerinin sınıflarında karşılaştıkları öğrenci davranış problemleri, bu problemlerin öğretme-öğrenme sürecine etkileri ve bunları yönetme stratejileri. Uluslararası Liderlik Eğitimi Dergisi,1(1), 1-10.

Tertemiz, N. (2012). Sinnf yönetimi. Leyla Küçükahmet (Ed.).13.Baskı. Pegem Akademi.

Toytok, E., ve Yıldırım, M. (2018). Meslek liselerinde disiplin sorunları ve nedenleri. Abant İzet Baysal Üniversitesi Eŏitim Fakültesi Dergisi,18, 1759-1778.

Tunç, B., İnand, Y., Öksüz, F. ve Çal, S. (2013). Eğitimde çok bileşenli değerlendirme: Velilerin okul yöneticilerinin performans değerlendirmesine katilım. Trakya Üniversitesi Eğitim Fakültesi Dergisi, 3(1), 90-99.

Tunç, B., Ylldız, S. ve Doğan, A. (2015). Meslek liselerinde disiplin sorunları, nedenleri ve çözümü bir durum analizi. Abant İzzet Baysal Üniversitesi Eğitim Fakültesi Dergisi. 15 (2), 384-403.

Tuzgöl Dost, M. ve Keklik, İ. (2012). Alanda çalışanların gözünden psikolojik danışma ve rehberlik alanının sorunları. Mehmet Akif Ersoy Üniversitesi Eğitim Fakültesi Dergisi, 1(23), 389-407.

Tümkaya, S. (2005). Öğretmenlerin sınıf içi disiplin anlayışları ve tükenmişlikle ilişkisi. Kuram ve Uygulamada Eğitim Yönetimi, 44, 549-568.

Uysal, H. Altun, S. A. ve Akgün, E. (2010). Okulöncesi öğretmenlerinin çocukların istenmeyen davranışları karşısında uyguladıkları stratejiler. Ilköğretim Online, 9(3), 971-979.

Weber, W. A. (2003). Classroom management, J.M. Cooper (Ed.), Classroom Teaching Skills (6.Edition), 222-265, New York: Houghton Mifflin Company.

Wehby, J. H., Tally, B. B. and Falk, K. B. (2004). Identifying the relation between the function of student problem behavior and teacher instructional behavior. Assessment for effective intervention, 30(1), 41-51.

Wolfgang, C. H. (2001). Solving discipline and classroom management problems: Methods and models for today's teachers. Wiley: Jossey-Basseduc.

Yahaya, A.,Ramli, J., Hashim, S., Ibrahim, M. A., Rahman, R. R. R. A. and Yahaya, N. (2009). Discipline problems among secondary school students in JohorBahru, Malaysia. European Journal of Social Sciences, 11(4), 659-675.

Yavuzer, H. (2013). Ana-baba-çocuk. 24. Baskı. Remzi Kitabevi.

Yıldırım, İ. (2010). Sinıf içi disiplin sorunları ile ana baba tutumları arasındaki ilişki. (Yayımlanmamış yüksek lisans tezi). Atatürk Üniversitesi, Erzurum.

Yılmaz, F. ve Babaoğlan, E. (2013). Sınıf öğretmenlerinin disiplini sağlamada kullandıkları ödül ve ceza yöntemleri (Şırnak İli Örneği). İlköğretim Online,12(1), 36-51. 
Yücesoy, K. Ö. (2017). Liselerde öğrencilerin disiplinsiz davranışları ve sebepleri (Sarayköy örneği) (Tezsiz yüksek lisans projesi). Pamukkale Üniversitesi, Denizli.

Zachos, D. T., Delaveridou, A. and Gkontzou, A. (2016). Teachers and School “Discipline" in Greece: A Case Study. European Journal of Social Science Education and Research, 3(3), 8-19.

\section{Kaynakça Bilgisi / Citation Information}

Sadık, F. ve Yalçın, O.(2021). Liselerde disiplin uygulamalarına yönelik öğretmen ve öğrenci görüşleri. OPUS-Uluslararası Toplum Araştırmaları Dergisi, 18(40), 2530-2585. DOI: 10.26466/opus.868503. 